\title{
Beyond Cell-Cell Adhesion: Sensational Cadherins for Hearing and Balance
}

\author{
Avinash Jaiganesh, Yoshie Narui, Raul Araya-Secchi, and Marcos Sotomayor \\ Department of Chemistry and Biochemistry, The Ohio State University, Columbus, Ohio 43210 \\ Correspondence: sotomayor.8@osu.edu
}

Cadherins form a large family of proteins often involved in calcium-dependent cellular adhesion. Although classical members of the family can provide a physical bond between cells, a subset of special cadherins use their extracellular domains to interlink apical specializations of single epithelial sensory cells. Two of these cadherins, cadherin-23 (CDH23) and protocadherin-15 (PCDH15), form extracellular "tip link" filaments that connect apical bundles of stereocilia on hair cells essential for inner-ear mechanotransduction. As these bundles deflect in response to mechanical stimuli from sound or head movements, tip links gate hair-cell mechanosensitive channels to initiate sensory perception. Here, we review the unusual and diverse structural properties of these tip-link cadherins and the functional significance of their deafness-related missense mutations. Based on the structural features of $\mathrm{CDH} 23$ and PCDH15, we discuss the elasticity of tip links and models that bridge the gap between the nanomechanics of cadherins and the micromechanics of hair-cell bundles during inner-ear mechanotransduction.

\begin{abstract}
dhesion molecules maintain cell-cell juncAtions in multicellular organisms, providing physical bonds between neighboring cells through interactions of their extracellular domains. Cadherins form one of the largest families of adhesion molecules with more than 100 members encoded in the human genome (Takeichi 1990; Suzuki 1996; Junghans et al. 2005; Hulpiau and van Roy 2011; Hirano and Takeichi 2012; Sotomayor et al. 2014). Classical cadherins, which have been the most extensively studied, mediate calcium-dependent cellular adhesion through interactions of their extracellular cadherin repeats (Brasch et al. 2012). The two founding members of the classical cadherin subfamily, E- and N-cadherin (CDH1 and $\mathrm{CDH} 2)$,
\end{abstract}

are essential for embryo and brain morphogenesis (Kemler et al. 1977; Takeichi 1977; Bertolotti et al. 1980; Hatta et al. 1985), and have been implicated in a plethora of biological processes and diseases (van Roy and Berx 2008; Radice 2013). Less is known about other cadherins present in junctions between different compartments of the same cell, such as in apical specializations of photoreceptors in the eye, enterocytes in the gut, and hair cells of the inner ear.

In photoreceptor cells, protocadherin-21 $(\mathrm{PCDH} 21)$ has been implicated in extracellular adhesion necessary for morphogenesis of the outer segment, connecting nascent discs to the inner segment of the same cell (Burgoyne et al. 2015). Similarly, protocadherin-24 (PCDH24)

Editors: Carien M. Niessen and Alpha S. Yap

Additional Perspectives on Cell-Cell Junctions available at www.cshperspectives.org

Copyright (C) 2018 Cold Spring Harbor Laboratory Press; all rights reserved; doi: 10.1101/cshperspect.a029280

Cite this article as Cold Spring Harb Perspect Biol 2018;10:a029280 
A. Jaiganesh et al.

and the mucin-like protocadherin (CDHR5) have been shown to interact to form intermicrovillar links that connect microvilli on the surface of epithelial enterocytes (Crawley et al. 2014). In the inner ear, cadherin-23 (CDH23) and protocadherin-15 (PCDH15) form tip link filaments in hair cells essential for hearing and balance (Siemens et al. 2004; Söllner et al. 2004; Ahmed et al. 2006; Kazmierczak et al. 2007; Corey 2007). In all three cases, the cadherins involved interconnect apical specializations within a single cell and are structurally distinct from classical members of the family. In addition, their cytoplasmic molecular binding partners go beyond the classical $\beta$-catenin paradigm, and their mechanisms of interaction and function have not been fully determined. In this review, we will focus on recent advances in the study of $\mathrm{CDH} 23$ and PCDH15 function in hearing and balance.

\section{INNER-EAR HAIR-CELL MECHANOTRANSDUCTION AND CADHERIN TIP LINKS}

In the mammalian inner ear, mechanical stimuli from sound or head movements are converted into electrical signals triggering sensory perception through a process called mechanotransduction (Von Békésy 1956; Pickles and Corey 1992; Reichenbach and Hudspeth 2014). This process is performed by hair cells (Fig. 1A), specialized mechanoreceptor cells in the cochlear and vestibular sensory epithelia (Davis 1965; Gillespie and Müller 2009; Fettiplace and Kim 2014). As hearing occurs, sound waves travel through air into the ear and are transformed into fluid pressure waves that move through the cochlea to stimulate cochlear hair cells. Similarly, head movements displace a gelatinous mass or crystalline structures (otoliths) to stimulate the inner-ear vestibular hair cells that mediate the sense of balance (Angelaki and Cullen 2008; Eatock and Songer 2011).

As their name suggests, hair cells feature an apical bundle of hair-like projections called stereocilia (Fig. 1A,B). Each stereocilium is primarily made of rigid actin filaments surrounded by plasma membrane (Flock and Cheung 1977;
DeRosier et al. 1980). Hair-cell stereocilia bundles, protruding from a single cell, are the sites of transduction and have different shapes, sizes, and morphologies depending on species, organ, location within the organ, and developmental stage (Schwander et al. 2010). Cochlear inner hair cells (IHCs) generally display three rows of stereocilia forming a largely linear bundle, whereas cochlear outer hair cells (OHCs) have three stereocilia rows forming a $\mathrm{V}$-shaped bundle (Fig. 1A). Vestibular hair bundles have five or more rows arranged in a hexagonal matrix. Yet, common to all wild-type hair-cell bundles is a staircase-like arrangement of their stereocilia rows from shortest to tallest (Belyantseva et al. 2003, 2005), which defines the polarity and excitatory axis of hair cells (Fig. 1B,C). As hair-cell bundles are stimulated, stereocilia move as rigid rods back and forth along the excitatory axis to initiate transduction and sensory perception (Hudspeth and Corey 1977; Corey and Hudspeth 1983; Fettiplace and Kim 2014).

Stereocilia in bundles are connected to each other at various points along their length (Hackney et al. 2013). Ankle links, made of VLGR1 and possibly usherin, hold the overall bundle structure together by interconnecting stereocilia bases (McGee et al. 2006; Michalski et al. 2007). Shaft connectors, made of PTPRQ (Goodyear et al. 2003), and transient lateral links (CDH23 and PCDH15) connect the sides of stereocilia during development and disappear as hair cells mature (Michel et al. 2005). Horizontal top connectors link the upper sides of stereocilia to their tallest neighbors and are possibly formed by stereocilin (Verpy et al. 2011). Kinocilial links (CDH23 and PCDH15) connect the tallest stereocilium to the kinocilium, a single true cilium present in all hair bundles that is lost in mature mammalian cochlear hair cells (Goodyear and Richardson 2003; Goodyear et al. 2010). Finally, tip links are defined as the oblique links between the tip of each stereocilium to the side of its taller neighbor (Fig. 1B) (Pickles et al. 1984). These are the only hair-cell bundle filaments directly involved in transduction and are formed by CDH23 and PCDH15 (Fig. 1D) in rodent, fish, avian, and human inner ears (Siemens et al. 2004; Söllner et al. 2004; Ahmed et al. 2006; 

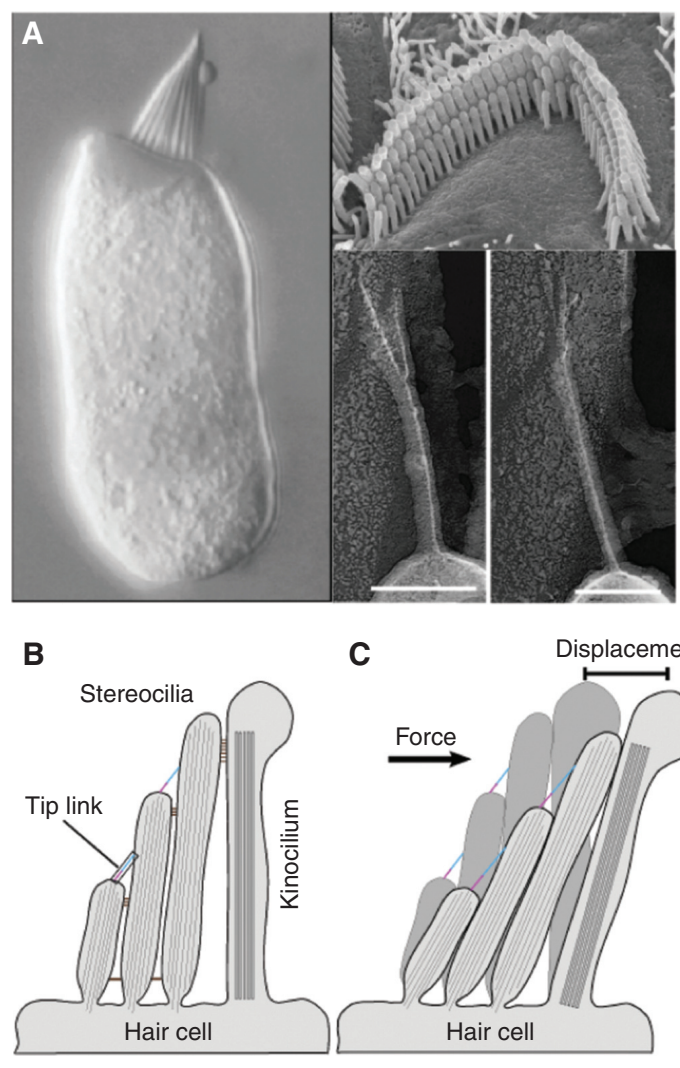

C
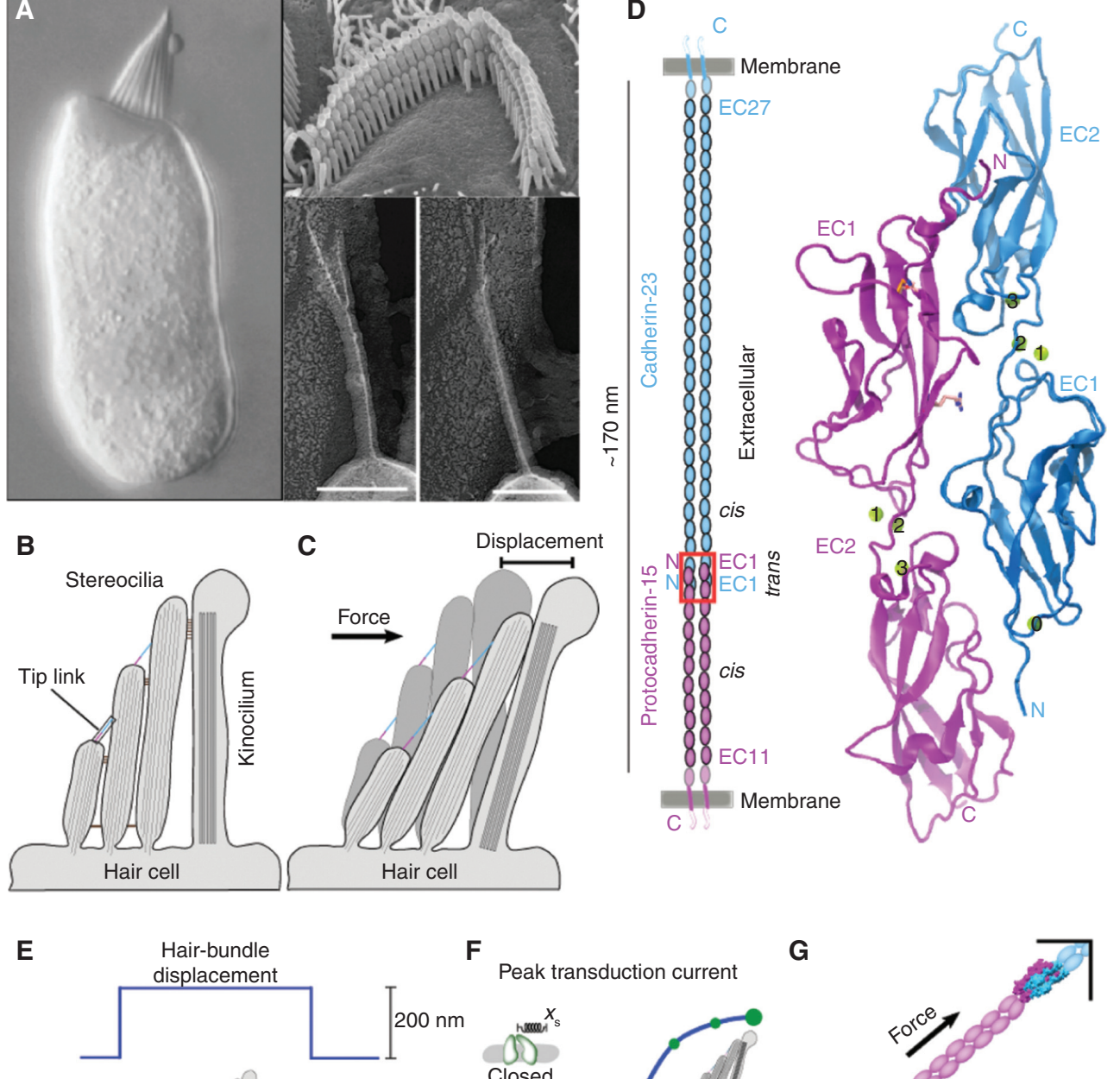

$\mathbf{F}$ Peak transduction current
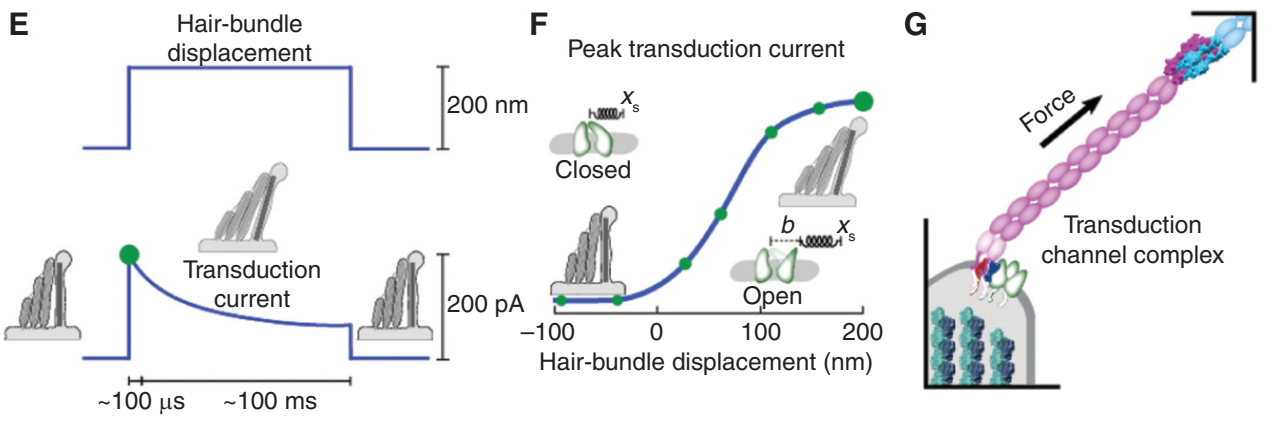

Figure 1. Hair cell mechanotransduction and the cadherin tip link. (A) High-resolution images of a bullfrog hair cell (left), a mammalian cochlear outer hair cell ( $\mathrm{OHC}$ ) stereocilia bundle (top right), and tip links (bottom right). The hair bundle sits on the apical surface of the hair cell, and tip links connect the tip of each stereocilium to the side of the taller neighbor. See schematics in B. (Image A left is reprinted from Hudspeth 1985, with permission from American Association for the Advancement of Science; Image A top right is reprinted from Furness et al. 2008; Image A bottom right is reprinted from Kachar et al. 2000, courtesy of The National Academy of Sciences.) Bars represent $100 \mathrm{~nm}$. (B) Schematic representation of a cochlear stereocilia bundle highlighting the location of the tip link. (C) Bundle deflection results in increased tip-link tension. (D) The tip link is formed by the tip-to-tip (trans) interaction of protocadherin-15 (PCDH15) and cadherin-23 (CDH23). Both proteins occur as parallel (cis) homodimers. Red box shows location of the CDH23-PCDH15 handshake interaction shown on the right (Sotomayor et al. 2012). Proteins are shown as ribbons and calcium ions as green spheres. Residue p.R139 (p.R113 without signal peptide) mutated in deafness and a disulfide bond at the tip of PCDH15 are shown as sticks. (E) Hair-bundle displacement (top) results in fast opening of transduction channels as shown by the rapid increase in transduction current $($ bottom). $(F)$ Peak currents (green dot in panel $E$ ) plotted as a function of hair bundle displacement show a sigmoidal relationship that can be reproduced by gating spring models (Sukharev and Corey 2004). (G) Mechanotransduction apparatus. The tip link conveys force to transduction channels at the top of the stereocilium. 
A. Jaiganesh et al.

Kazmierczak et al. 2007; Goodyear et al. 2010; Alagramam et al. 2011).

Tip links are essential components of the inner-ear mechanotransduction apparatus. As stereocilia bundles are deflected toward the tallest stereocilium in response to mechanical stimuli, tension builds up in the oblique tip links, which force open ion channels located at the base of the filaments near the top of each stereocilium (Assad et al. 1991; Beurg et al. 2009). Opening of these cation-selective channels by tip links results in potassium influx, haircell depolarization, and a subsequent release of neurotransmitters at the synapses located at the base of hair cells. These are the first steps in sensory perception mediated by hair cells (Fig. 1E-G).

Unlike other components of the transduction apparatus, the molecular identity of tip links is well defined. Multiple deletions, nonsense, and missense mutations confirm the involvement of both $\mathrm{CDH} 23$ and $\mathrm{PCDH} 15$ in hearing loss in various species (Alagramam et al. 2001b, 2011; Di Palma et al. 2001a). Antibody labeling localizes $\mathrm{CDH} 23$ to the upper end of tip links, and PCDH15 to their lower end (Kazmierczak et al. 2007; Indzhykulian et al. 2013). The predicted length for the combined extracellular domains of $\mathrm{CDH} 23$ and PCDH15 $(\sim 170 \mathrm{~nm})$ matches well the range of tip link sizes observed by electron microscopy (150 to $185 \mathrm{~nm}$ ) (Furness et al. 2008). The calciumdependent integrity of tip links, which are disrupted with the calcium chelator BAPTA, is also consistent with cadherin's sensitivity to calcium (Assad et al. 1991; Pokutta et al. 1994; Kazmierczak et al. 2007; Furness et al. 2008). Moreover, crystal structures of the CDH23 and PCDH15 tips bound to each other, in vitro biochemical assays, and the Noddy mouse model (see below) support the notion that the heterophilic $\mathrm{CDH} 23$ and PCDH15 interaction is essential for tip link formation (Sotomayor et al. 2012; Geng et al. 2013).

Direct involvement of tip links in hair-cell channel gating is also well established. First, fast opening of transduction channels (50 to $200 \mu \mathrm{s})$ during hair-bundle deflection cannot be accounted for by slow enzymatic or second- ary messenger models (Corey and Hudspeth 1983). Correlation of tip link disappearance through BAPTA treatments with the absence of transduction currents further highlights their relevance during transduction (Assad et al. 1991; Zhao et al. 1996). In addition, the alignment of tip links along the excitatory axis of hair cells and their oblique orientation allow them to convey force to either of their ends (Shotwell et al. 1981; Pickles et al. 1984). Localization of the site of transduction through calcium imaging at the lower end of tip links, near PCDH15, further supports a direct involvement of tip links in gating (Beurg et al. 2009). Finally, recent experiments show that direct mechanical stimulation of $\mathrm{CDH} 23$, expected to be connected to PCDH15 and the transduction channel, elicits hair-cell transduction currents (Basu et al. 2016). These results unequivocally place the cadherin tip link as the core component of the transduction apparatus that directly gates transduction channels.

\section{PHYSICS OF MECHANOTRANSDUCTION AND GATING SPRING MODEL}

Matching the electrophysiological and microscopic mechanical response of hair-cell bundles to the expected mechanical behavior of the molecules that form the hair-cell transduction apparatus has been challenging. The extent of bundle displacement under physiological conditions, the endogenous forces that a single tip link withstands during transduction, and the natural resting tension on individual tip links have all been estimated from exquisite but indirect measurements that often involve data from the whole hair-cell bundle (Howard and Hudspeth 1988; Jaramillo and Hudspeth 1993; Cheung and Corey 2006). These measurements are often interpreted using a theoretical model that can capture and reproduce the essential features of hair-cell transduction recordings by assuming that ion channels are directly attached and gated by a hypothetical spring of unknown molecular identity (Corey and Hudspeth 1983).

In the simplest version of this "gating spring" model, the transduction channel open probability $p_{o}$ is obtained from a two-state Boltz- 
mann distribution with

$$
p_{o}=\frac{1}{1+e^{\Delta g / k_{B} T}},
$$

where $\Delta g$ is the energy difference between the open and closed states, $k_{B}$ is the Boltzmann constant, and $T$ is the temperature. Assuming that the channel gate swings a distance $b$ (Fig. 1F), and that the force applied to it through the gating spring is $f$, then the energy difference $\Delta g$ can be written as

$$
\Delta g=-f b+\Delta u
$$

where $f b$ is the work done during channel opening, and $\Delta u$ is the intrinsic energy difference between open and closed states of the channel in the absence of force (Sukharev and Corey 2004). The position of the free end of the spring $x_{s}$ will be

$$
x_{s}=\frac{f}{k_{g}}+b p_{o} \text {, }
$$

where $k_{g}$ is the spring constant of the gating spring, $f / k_{g}$ is the extension of the spring, and $b p_{o}$ is the extension caused by channel opening. This model can be used to obtain $k_{g}, b$, and $\Delta u$ from experiments where the force applied to the system is kept constant, $x_{s}$ is inferred from the bundle position, and the open probability is deduced from recorded currents. A similar model can be obtained for experiments in which the position of the bundle is held constant while force and open probability are monitored. More advanced models may incorporate additional terms accounting for myosin-mediated adaptation, calcium-dependent reclosure of the channel, and other biophysical phenomena relevant for hair-cell transduction.

Electrophysiological data measured from hair cells and interpreted within the context of the gating spring theory suggest that transduction channels are gated rapidly (50 to $200 \mu \mathrm{s}$ ) by piconewton forces applied through a gating spring connected in series and with a stiffness of $\sim 0.5$ to $1 \mathrm{mN} / \mathrm{m}$. The channel gate swing is estimated to be $\sim 4 \mathrm{~nm}$, the resting tension in the system is $\sim 10 \mathrm{pN}$, and the stretching range is $>100 \mathrm{~nm}$ (Corey and Hudspeth 1983; Howard and Hudspeth 1988; Jaramillo and Hudspeth 1993; Corey and Howard 1994; Shepherd and Corey 1994; Cheung and Corey 2006). The tip link, membrane deformation, scaffolding proteins, and myosin adaptation motors may all contribute to the soft gating spring elasticity measured during transduction (Pickles et al. 1984; Howard and Spudich 1996; Powers et al. 2012, 2014). Yet, the structural properties of the known components of the transduction apparatus put some constraints on what each part can contribute. A better understanding of the diverse and exceptional structural features of the $\mathrm{CDH} 23$ and $\mathrm{PCDH} 15$ proteins can thus further guide a more comprehensive and multi-scale model of hair-cell mechanotransduction.

\section{STRUCTURAL DETERMINANTS OF CADHERIN-23 FUNCTION}

Members of the cadherin family of proteins feature at least two extracellular cadherin (EC) repeats, a transmembrane domain that in most cases involves a single $\alpha$-helix, and a carboxyterminal cytoplasmic domain (Brasch et al. 2012; Hirano and Takeichi 2012; Sotomayor et al. 2014). The EC repeats are similar in fold and sequence, but not identical to each other (Figs. 1D, 2A). Classical cadherins have five EC repeats, whereas clustered protocadherins have six, and other family members have up to $34 \mathrm{EC}$ repeats. In all cases, the EC segment is defined by calcium-binding sites at the linker region between consecutive EC repeats (Ringwald et al. 1987; Nagar et al. 1996; Boggon et al. 2002). These sites are highly conserved and often feature three calcium ions coordinated by negatively charged residues at motifs in the preceding EC repeat (XEX and DXE), the linker between the EC repeats $(\mathrm{DXNDN})$, and the following EC repeat (DXD and XDX; Fig. 2B,D). Calcium binding at these sites rigidifies consecutive EC repeats, and also enhances mechanical strength and resistance to unfolding in classical cadherins (Pokutta et al. 1994; Cailliez and Lavery 2005; Sotomayor and Schulten 2008; Oroz et al. 2011). 
A. Jaiganesh et al.
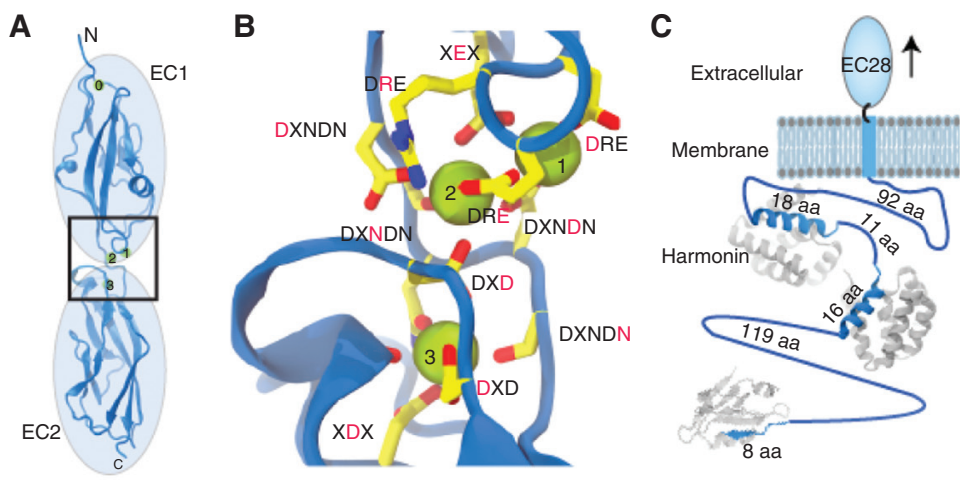

D

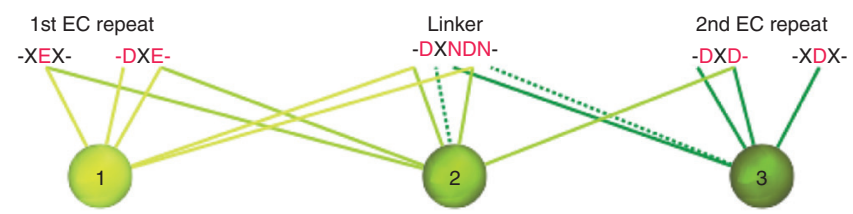

E
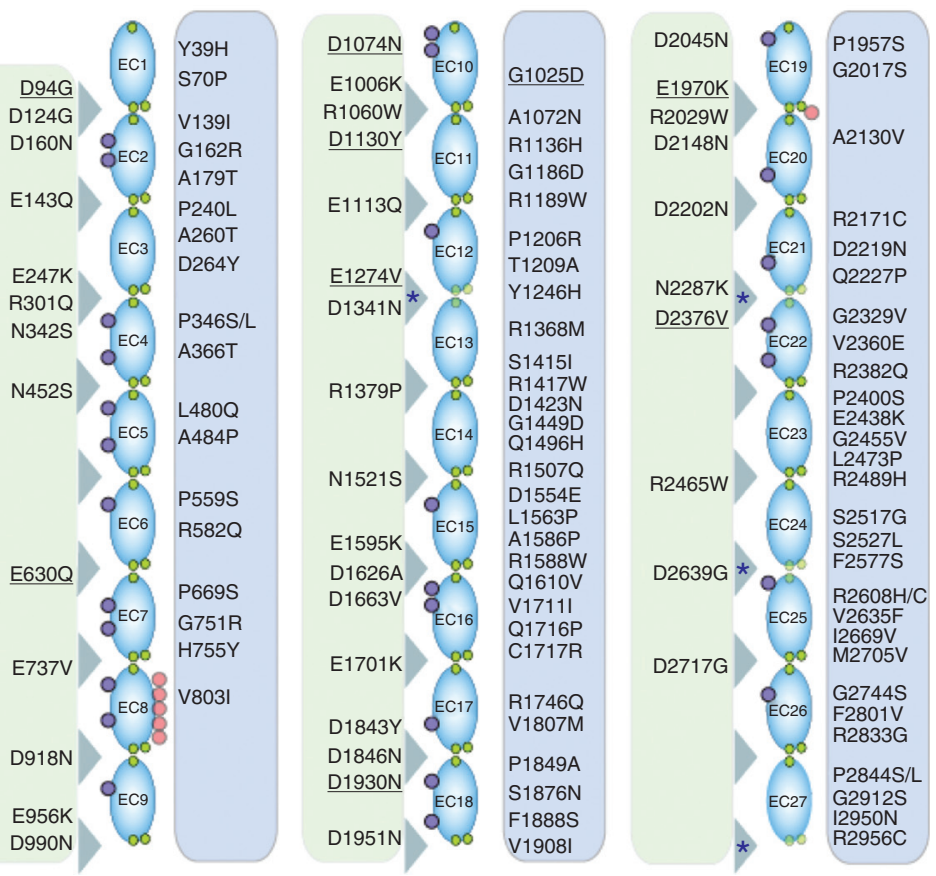

Figure 2. Structural determinants of cadherin-23 (CDH23) function. (A) Structure of CDH23 EC1-2 (Sotomayor et al. 2010). (B) Canonical calcium-binding site between EC1-2 highlighting conserved residues involved in calcium coordination. Calcium ions are shown as green spheres. (C) Schematic of the cytoplasmic domain of CDH23 (blue) with structurally solved fragments bound to harmonin (gray) (Pan et al. 2009; Wu et al. 2012). (D) Calcium-binding sequence motifs and coordination of calcium ions at sites 1,2, and 3. Dashed lines indicated coordination by backbone oxygen. (E) Mapping of missense mutations causing deafness along the extracellular domain of $\mathrm{CDH} 23$ (EC1 to EC27; residue numbers include signal peptide). Green columns (left) highlight mutations to calcium-binding residues. Underlined mutations are presumed pathogenic based on phenotype and predicted structural effect. All others are inferred pathogenic based on phenotype and genetic studies. Blue asterisks at linkers indicate unusual calcium-binding motif sequences. Purple and red circles indicate predicted $\mathrm{N}$ - and O-linked glycosylation sites. 
$\mathrm{CDH} 23$, forming the upper three fourths of the tip link, is unique in that its longest isoform features $27 \mathrm{EC}$ repeats with a predicted length of at least $120 \mathrm{~nm}(4.5 \mathrm{~nm}$ per EC repeat from known canonical structures) (Di Palma et al. 2001b). This extraordinarily long extracellular domain makes CDH23 ideally suited to function as part of the $\sim 170 \mathrm{~nm}$-long tip link (Fig. 1D). The structures for the EC1-2 tip of $\mathrm{CDH} 23$ (Fig. 2A), by itself and in complex with PCDH15 EC1-2, show EC repeats forming a typical Greek-key fold made of seven $\beta$-strands each (Elledge et al. 2010; Sotomayor et al. 2010, 2012). A calcium ion at an atypical binding site at the amino terminus of EC1 (site 0) keeps loops and $\beta$-strands together and, as expected, three calcium ions are bound at the canonical linker region between the repeats (Fig. 2B). Measurements of binding affinity for calcium in EC1-2 suggest that site 3 has the highest affinity with a $K_{\mathrm{D}}$ of $\sim 5 \mu \mathrm{M}$, whereas sites 2 and 1 have $K_{\mathrm{D}}$ values of $\sim 44$ and $\sim 71 \mu \mathrm{M}$ (Sotomayor et al. 2010). Calcium concentration in the inner ear is tightly controlled, and it may range from 20 to $40 \mu \mathrm{M}$ in the endolymph fluid that bathes cochlear hair cells, or from 100 to $300 \mu \mathrm{M}$ in vestibular endolymph (Bosher and Warren 1978; Salt et al. 1989). Thus, sites 2 and 3 are likely occupied during transduction in canonical tiplink EC repeats, yet binding affinities for all sites throughout the extracellular domain of $\mathrm{CDH} 23$ and local calcium concentrations around tip links remain to be determined (Mammano et al. 2007; Ceriani and Mammano 2012).

Equilibrium and steered molecular dynamics (MD) simulations of the CDH23 EC1-2 structure revealed three important aspects of its nanomechanics (Sotomayor et al. 2010). First, the flexural rigidity of EC1-2 is controlled by calcium binding, with the EC1-2 linker behaving as a loose hinge when calcium is absent. Second, calcium is also important for the linear mechanical strength of EC repeats, with calcium ions at sites 2 and 3 being responsible for a twofold increase in the force required to mechanically unfold a pair of EC repeats. Last, simulations suggest that EC1-2 and similar canonical EC repeats are stiff, with a predicted spring constant of at least $\sim 700 \mathrm{mN} / \mathrm{m}$ per re- peat at a stretching speed of $0.1 \mathrm{~nm} / \mathrm{ns}$ (before unfolding occurs). A tip link made of two strands with $27+11$ EC repeats like EC1-2 each would have an effective spring constant of $\sim 37 \mathrm{mN} / \mathrm{m}$ at a stretching speed of $0.1 \mathrm{~nm} /$ ns, too large for what is expected for the gating spring $(0.5 \mathrm{mN} / \mathrm{m}$ from equilibrium measurements). However, this estimate does not take into account the elasticity that could stem from noncanonical linkers and from rearrangements of the monomers within a superhelical dimer of CDH23 molecules.

Sequence analyses of all CDH23 EC repeats indicate that most of them are canonical, similar to $\mathrm{CDH} 23$ EC1-2. However, structures of repeats EC3 to EC27 are unknown, and there are a few sequence variations that suggest the existence of calcium-deficient linkers that may lend $\mathrm{CDH} 23$ unique mechanical properties. For example, two variations in calcium-binding motifs at the CDH23 EC12-13 linker (SXD replaces DXD and NELDE replaces DXNDN) may affect calcium coordination at its site 3 (Fig. 2D,E). Similarly, the DRE motif is NRE at the EC2122 linker and SYE at the EC24-25 linker, which might affect calcium binding at site 1 in each case (Fig. 2D,E). In addition, the XDX motif at the top of EC26 is missing, compromising coordination of calcium at site 3 in the EC25-26 linker (Fig. 2D,E). Last, EC27 connects to a stretch of about 100 residues that may fold as a possible EC28 repeat next to the transmembrane helix of CDH23. The EC27-28 linker does not have any of the calcium-binding motifs typically present in cadherins. Further structural information from all these EC repeats is needed to determine the elasticity of their atypical linkers and the exact role that $\mathrm{CDH} 23$ plays in the gating spring model of mechanotransduction.

\section{STRUCTURAL DETERMINANTS OF PROTOCADHERIN-15 FUNCTION}

PCDH15, which forms the lower end of tip links (Alagramam et al. 2001a; Ahmed et al. 2001, 2006), is shorter than CDH23 but has a similar overall architecture. The extracellular domain of PCDH15 has 11 EC repeats, followed by a single transmembrane helix and a large cytoplasmic 
A. Jaiganesh et al.

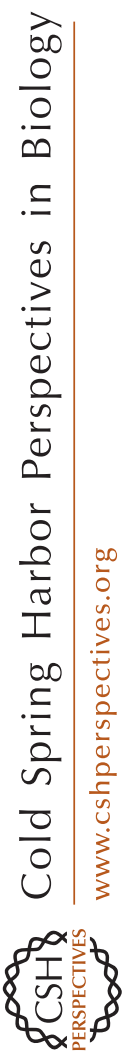

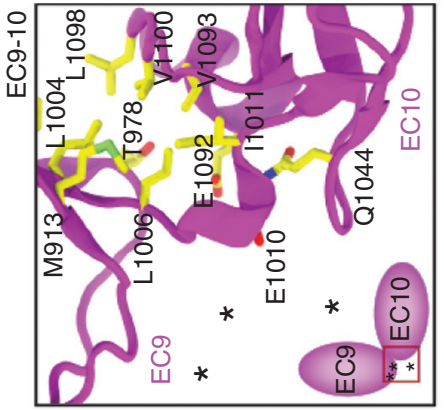
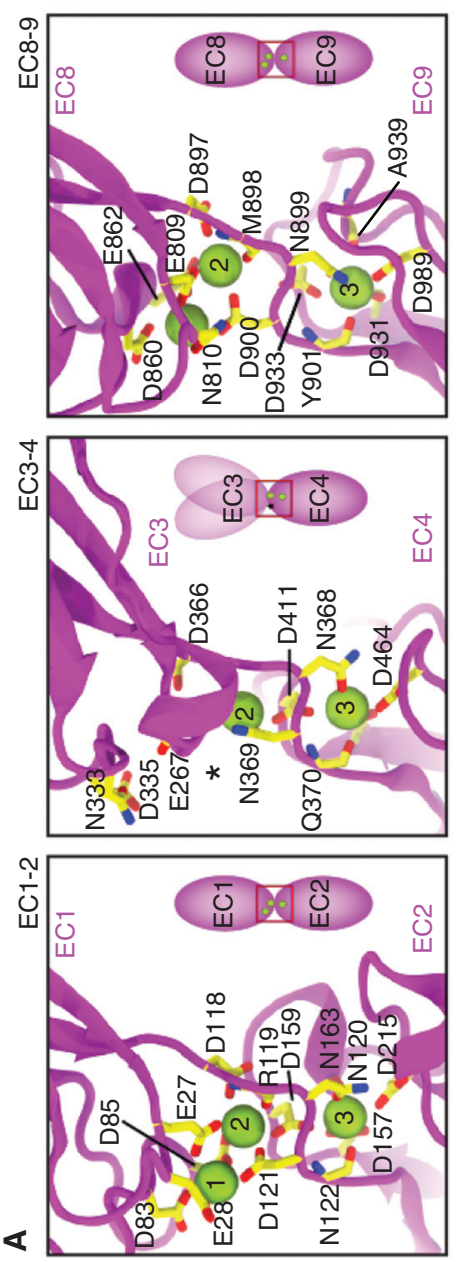

$\mathbf{m}$
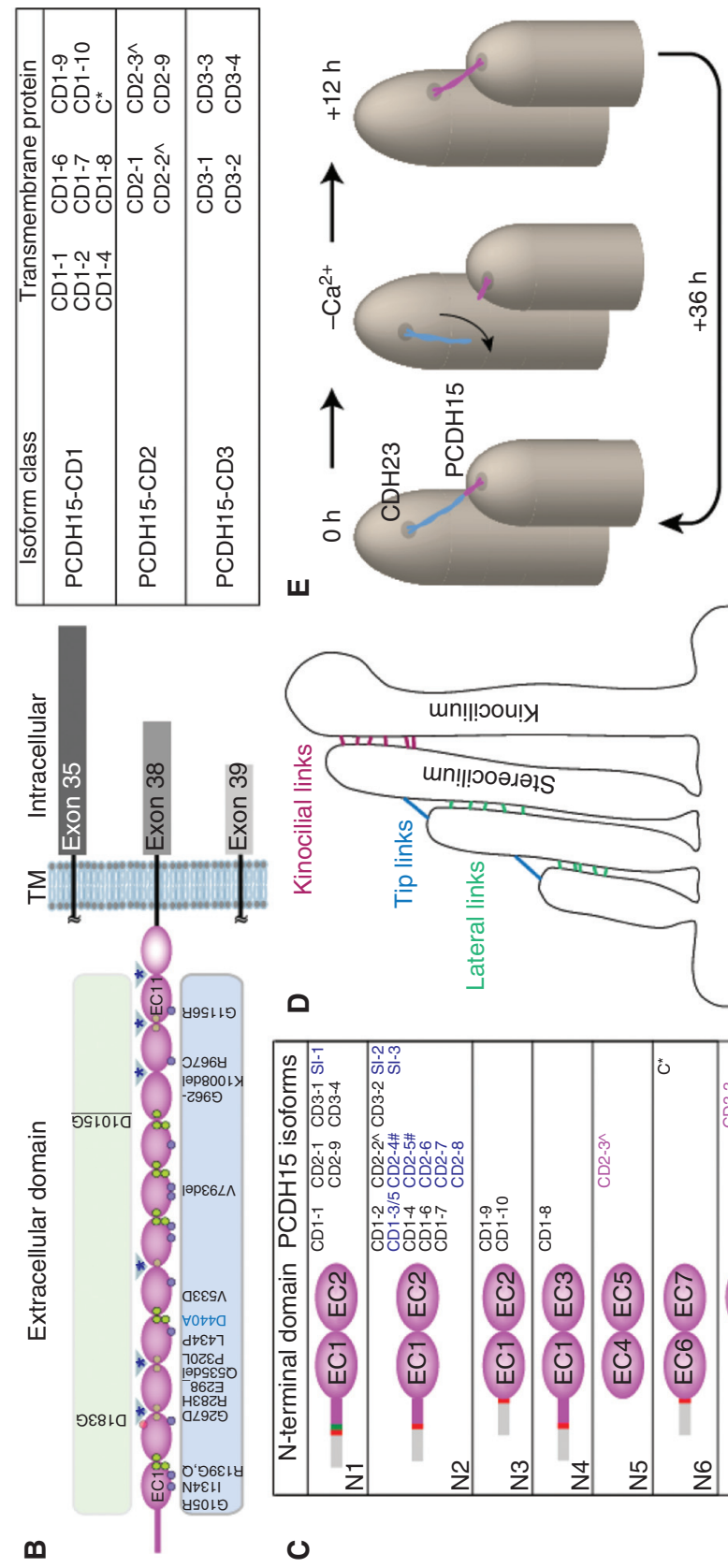

$\boldsymbol{\omega}$
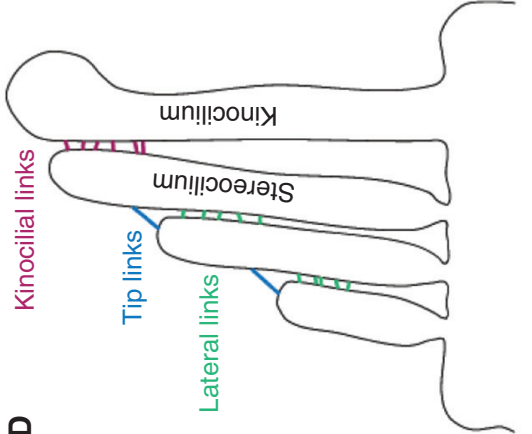

口

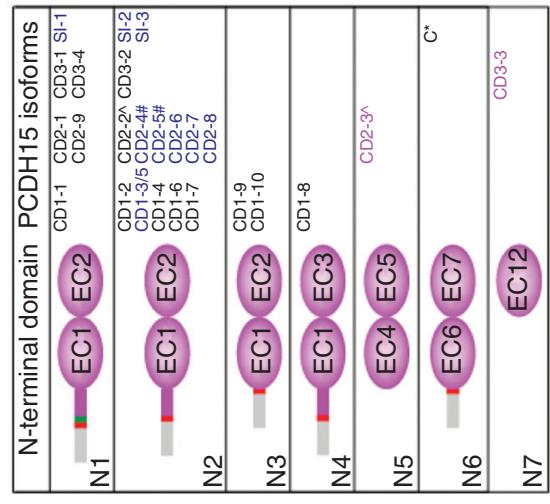

0 
domain (up to 541 residues, depending on the isoform). The predicted length of the PCDH15 extracellular domain (EC1-11) is $~ 50 \mathrm{~nm}$, which when added to the length of the extracellular domain of CDH23 $(\sim 120 \mathrm{~nm})$, would be compatible with a tip-to-tip interaction for a $\sim 170 \mathrm{~nm}$ long tip link (Fig. 1D,G). The structure of PCDH15 EC1-2 (solved in complex with CDH23 EC1-2; Fig. 1D) revealed a pair of EC repeats with typical cadherin fold, but with a unique intramolecular disulfide bond at the top of EC1 that keeps loops and $\beta$-strands together as a calcium ion does in site 0 of $\mathrm{CDH} 23$ EC1 (Sotomayor et al. 2012). In addition, a rigid and bulky loop within $\beta$-strand A of PCDH15 tucks against the narrow wrist of the adjacent $\mathrm{CDH} 23$ linker, leading to an antiparallel heterodimeric "handshake" bond that has been validated in vitro and in vivo (Sotomayor et al. 2012; Geng et al. 2013). This handshake bond is consistent with the tip-to-tip antiparallel arrangement of PCDH15 and CDH23 expected for hair-cell tip links.

The PCDH15 EC1-2 structure within the handshake revealed straight repeats and an expected canonical linker with three bound calcium ions (Fig. 3A). However, sequence analyses for other parts of the PCDH15 extracellular domain suggest that its linkers are diverse. For instance, the DXNDN motif is modified in the linkers EC2-3 (DGDDL), EC3-4 (DENNQ),
EC5-6 (PPNNQ), EC9-10 (HPGEI), and EC1011 (DENNH), suggesting that these may not bind three calcium ions as canonical linkers do, with implications for their flexibility and mechanical strength. Recent PCDH15 structures including two of these linkers (EC3-4 and EC9-10) confirm their predicted atypical architecture (Araya-Secchi et al. 2016; Powers et al. 2017). In the first case, the EC3-4 linker is found in two conformations in the crystal, and in both it features calcium ions only at sites 2 and 3 (Fig. 3A), with affinities $\left(K_{\mathrm{D}}\right)$ of 45 and $>100 \mu \mathrm{M}$, respectively (Powers et al. 2017). In the second case, the PCDH15 EC9-10 linker is calcium-free, it has a unique $3_{10}$ helix located in the center and an atypical loop in EC10 that stabilizes a $\sim 90^{\circ}$ bent conformation (Figs. $3 \mathrm{~A}, 4 \mathrm{~A}$, C). This bent, "L" shaped conformation is unique and preferred, as indicated by two different crystals structures from mouse and human proteins that show the same bending, and by small-angle $\mathrm{X}$-ray scattering data confirming its presence in solution (Araya-Secchi et al. 2016).

The atypical linkers in EC3-4 and EC9-10 have a direct impact on the nanomechanics and elasticity of PCDH15. MD simulations predict that the EC3-4 linker with two bound calcium ions is more flexible than canonical linkers, a finding that is consistent with the two slightly bent conformations observed in the crystal structures. In addition, steered MD simulations

Figure 3. (Continued) Structural determinants of protocadherin-15 (PCDH15) function. (A) Canonical (EC1-2) and noncanonical (EC3-4, EC8-9, EC9-10) linkers of PCDH15 (Sotomayor et al. 2012; Araya-Secchi et al. 2016; Powers et al. 2017). Calcium ions are shown as green spheres. Location of missing ions is indicated with *. Residue numbers do not include signal peptide. (B) Isoform classes CD1, CD2, and CD3 are determined by the presence of exon 35 (479 aa), 38 (283 aa), or 39 (182 aa), respectively, in the cytoplasmic domain of PCDH15. Left, schematic of PCDH15 with all EC repeats and missense mutations and in-frame deletions known to cause deafness. Residue numbers include signal peptide. The D435 variation (blue) is predicted to be evolutionary advantageous (Grossman et al. 2010). The upper green column highlights missense mutations in calcium-binding residues as in Figure 2E. Purple and red circles show predicted $\mathrm{N}$ - and O-linked glycosylation sites. Blue asterisks at linkers indicate unusual calcium-binding motif sequences. Right, table of individual isoforms in each class that are predicted to be transmembrane proteins. An isoform that has a modified exon 35 is denoted with ${ }^{\star}$, whereas CD2 isoforms that do not have exon 38 are indicated with $\wedge$. (C) Comparison of amino-terminal domains (up to the first two EC repeats only) of PCDH15 isoforms. The schematic rectangular region defines the beginning of the amino terminus and is colored as follows: signal peptide in gray, exon 2 in gray and red, exon 3 in green, and exon 4 in purple. Labels of individual isoforms are highlighted in blue for secreted proteins, magenta for cytosolic proteins, and black for membrane proteins. Isoforms labeled with \# have alternate carboxy-terminal residues. $(D)$ Linkages in the hair bundle where PCDH15 is located throughout development. (E) Model proposing the transient formation of atypical tip links composed of PCDH15-PCDH15 proteins (Indzhykulian et al. 2013). 
A. Jaiganesh et al.
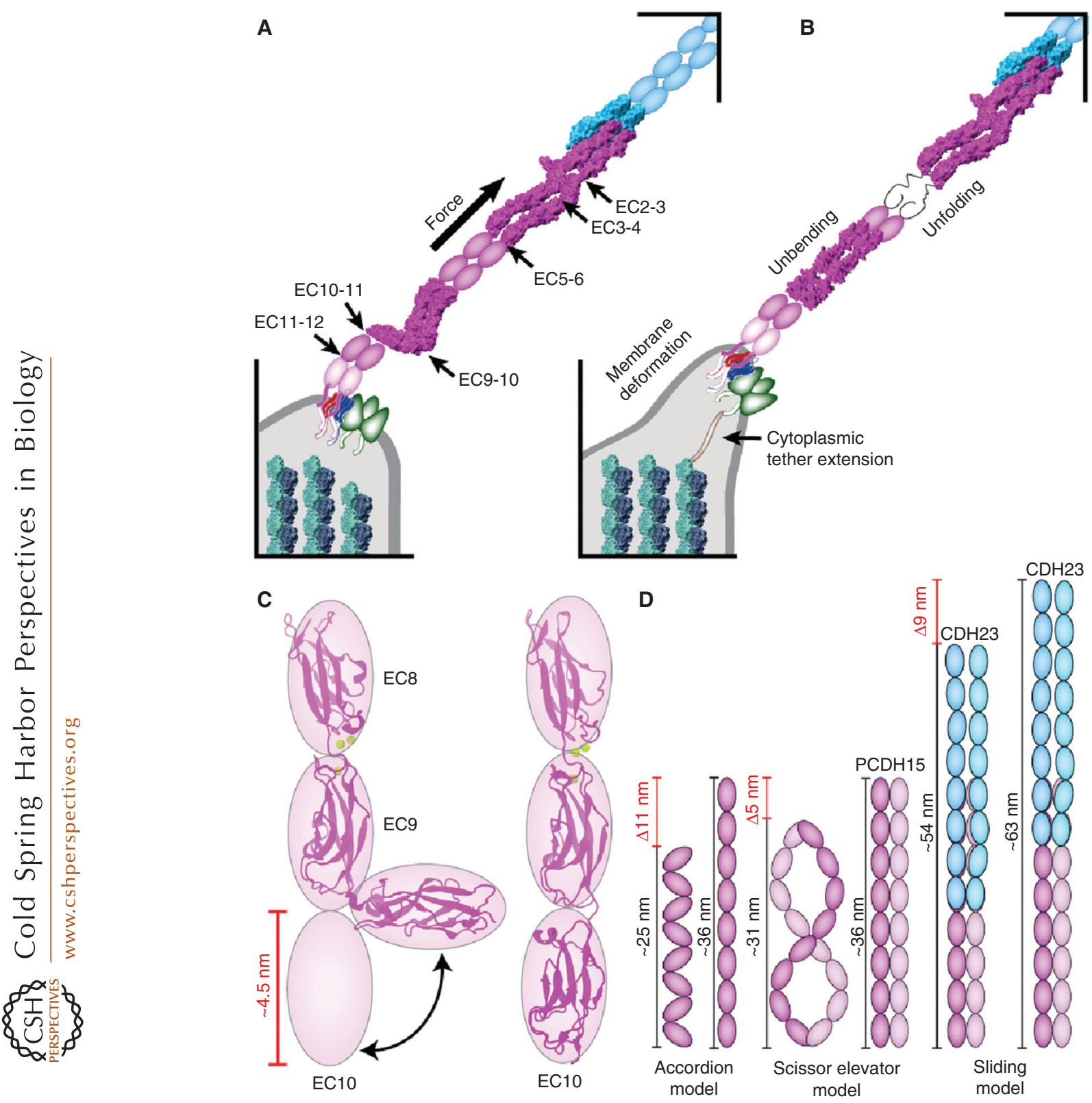

Figure 4. Structural basis of tip-link elasticity. $(A)$ Location of the noncanonical inter-repeat linkers in protocadherin-15 (PCDH15; magenta). Structures of the cadherin-23 (CDH23; blue) EC1-2 and PCDH15 EC1-2 handshake (4APX), PCDH15 EC3-5 (5T4M), and PCDH15 EC8-10 (4XHZ) with a bent EC9-10 calcium-free linker are shown in molecular surface representation. (B) Possible sources of gating-spring elasticity and extension: membrane deformation, cytoplasmic tether extension, unbending and/or unfolding of PCDH15 EC repeats. (C) Unbending of the PCDH15 EC8-10 structure observed by MD simulations (Araya-Secchi et al. 2016). $(D)$ Models of tip-link extensibility that involve tertiary structure rearrangements (accordion and scissor elevator models) and sliding of hypothetically overlapped tips. 
suggest that its increased flexibility does not dramatically compromise the EC3-4 mechanical strength, which is important to withstand physiological stimuli applied to tip links (Powers et al. 2017). In contrast, the bent EC9-10 linker remains fixed in a rather stable conformation unless a force larger than $10 \mathrm{pN}$ is applied to it, suggesting that it may remain bent even when subjected to physiological resting tension. Steered MD simulations of EC8-10 also suggest that unbending of EC9-10 provides some elasticity, with an effective spring constant of $\sim 8$ $\mathrm{mN} / \mathrm{m}$ at $0.02 \mathrm{~nm} / \mathrm{ns}$ and an extension of $\sim 4$ $\mathrm{nm}$ (Araya-Secchi et al. 2016). Further compliance may arise from the combined response of all atypical linkers in PCDH15, including a linker of unknown structure between EC11 and a possible EC12 repeat that connects to the transmembrane helix of PCDH15. The overall nanomechanics of full-length PCDH15 alone, in a parallel dimer, and in complex with $\mathrm{CDH} 23$ remains to be determined.

\section{GENETIC DETERMINANTS OF CADHERIN- 23 AND PROTOCADHERIN-15 FUNCTION}

Another layer of complexity in the analysis of the mechanical properties of $\mathrm{CDH} 23$ and PCDH15 is added by the existence of isoforms produced by alternative splicing (Lagziel et al. 2005; Ahmed et al. 2006; Takahashi et al. 2016). There are at least 11 isoforms documented for human CDH23 (Uniprot Q9H251), with four of them (isoforms 5, 6, 10, and 11) lacking a transmembrane domain. There are two major variations among the 7 isoforms that do have transmembrane domains. The first set of variations alter the amino-terminal extracellular domain, with isoforms 7 and 9 being shorter as they start at the end of EC21, effectively including six EC repeats along with EC28 on the extracellular side. The other five, isoforms 1 to 4 and isoform 8 , include the entire extracellular domain with repeats EC1-27 and EC28 and some minor in-frame insertions and deletions in EC2, EC4, and EC13. The second variation involves changes at the carboxyl terminus of the protein, with isoforms 4 and 9 lacking 35 residues (exon 68) in a cytoplasmic domain that otherwise would contain a total of 264 residues. Solution structures (Fig. 2C) have shown how some cytoplasmic fragments of $\mathrm{CDH} 23$, including part of exon 68 , bind to harmonin, a CDH23-binding protein, and connect it to the actin cytoskeleton (Kraemer and Yap 2003; Pan et al. 2009; Pan and Zhang 2012; Wu et al. 2012). Structural changes caused by these two major sequence variations and how they alter CDH23's homophilic and heterophilic binding capabilities as well as intracellular binding partners have yet to be fully resolved (Boëda et al. 2002; Siemens et al. 2004; Kazmierczak et al. 2007; Xu et al. 2008; Bahloul et al. 2010).

PCDH15 protein products seem to be even more diverse than $\mathrm{CDH} 23$, as there are at least 26 different isoforms with distinct extracellular and cytoplasmic domains (as documented in Uniprot Q99PJ1; Fig. 3B,C). PCDH15 can be categorized into one of three different classes based on the sequence of the intracellular domain (Ahmed et al. 2006), which is characterized by the presence of exon 31 encoding the single-pass transmembrane region, followed by a conserved membrane proximal domain and finally a variable region encoded by either exon 35, 38, or 39 (Fig. 3B). The presence of these exons generates three different isoform classes named CD1, CD2, and CD3, with a CD1 exemption featuring a modified exon 35 and two isoforms identified as CD2 but lacking exon 38 (Fig. 3B). A fourth class corresponds to potentially secreted isoforms (SI) that lack a transmembrane domain. Therefore, alternative splicing of PCDH15 may introduce a tremendous amount of diversity into linkages that are formed by PCDH15.

Localization of some CD isoforms of PCDH15 has been determined experimentally, although there are inconsistencies over where and when these appear in the inner ear. The precise location of PCDH15 isoforms is significant because formation of the tip link requires that the protein be located near the top of the stereocilium and close to the transduction channel. Initial studies indicated that in mature cochlear hair cells PCDH15-CD1 was found throughout the stereocilia, PCDH15-CD2 could not be detected, and PCDH15-CD3 was located 
A. Jaiganesh et al.

at the apex of the stereocilia (Ahmed et al. 2006). More recent studies have also localized PCDH15-CD2 at stereociliary tips using a different antibody for imaging by immunofluorescence and electron microscopy (Pepermans et al. 2014). These results suggest that either $\mathrm{CD} 2$ or CD3 are likely to be a part of the tip link and the transduction machinery, whereas other isoforms of PCDH15 are available to form alternative linkages within the hair cell bundle (Goodyear et al. 2010; Hackney et al. 2013).

The functional role of each cytoplasmic PCDH15 isoform in hearing remains an important open question within the field. Knockout mice were generated for each of the three cytoplasmic isoform classes, and the results showed that only PCDH15-CD2 deficient mice had unusual cochlear hair cell morphology and were deaf, although the vestibular function was preserved (Webb et al. 2011). In a conditional PCDH15-CD2 knockout mouse, hair-cell bundles developed normally, but after deletion of exon 38, tip links were lost and sound transduction was compromised (Pepermans et al. 2014). Further studies revealed that PCDH15-CD2 interacts with other likely members of the transduction machinery such as TMHS and TMIE (Xiong et al. 2012; Zhao et al. 2014). Together, this evidence strongly indicates that PCDH15CD2 is an integral part of the tip link filament and is an essential PCDH15 isoform for hearing, with the CD1 and CD3 isoforms functioning redundantly, and none of them being essential by themselves for vestibular function.

Interestingly, zebrafish have two protocadherin-15 paralogs, $p c d h 15 a$ that is required for hair cell mechanotransduction, and $p c d h 15 b$ that is expressed in the eye (Seiler et al. 2005). There are only two zebrafish Pcdh15a isoforms, CD1 and CD3, and Pcdh15a-CD3 interacts with transduction channel candidates TMC1 and TMC2 (Maeda et al. 2014, 2017). Yeast twohybrid assays and coimmunoprecipitation experiments suggest that the interaction between PCDH15-CD3 and TMC1/2 is also possible for mouse proteins, suggesting that this isoform is important for hair-cell mechanotransduction.

Current research has been primarily focused on the $\mathrm{CD}$ isoforms with variations in the intra- cellular domain of PCDH15 because of its close association with the hair-cell transduction channel. However, alternative splicing of PCDH15 leads to alterations not only in the intracellular domain but also the extracellular domain. The crystal structure of the tip link bond between PCDH15 and CDH23, along with genetic and biophysical studies have highlighted the significance of the first two EC repeats of each protein in hearing (Kazmierczak et al. 2007; Lelli et al. 2010; Sotomayor et al. 2012; Geng et al. 2013), so it is reasonable to expect that changes within the first EC repeats of PCDH15 could lead to important differences in tip link bond strength and may also affect other linkages within the hair-cell bundle where PCDH15 can be found (Fig. 3D).

The extracellular domains of PCDH15 can be divided into 7 groups based on the components found within the first two amino-terminal EC repeats (hereby labeled N1 to N7). The canonical PCDH15 isoform (CD1-1) and 5 other isoforms feature a signal peptide with the rest of exon 2, small exon 3 and exon 4 followed by the rest of their specific PCDH15 extracellular domain sequences (N1 in Fig. 3C). A second category of isoforms (N2) is similar to the canonical form except they lack small exon 3 (equivalent to a 5 residue in-frame deletion), and a third category lacks a portion of both exon 3 and exon 4 (equivalent to a 27 residue in-frame deletion). Four other groups of isoforms are missing significant portions of either the first or second EC repeat found in the canonical form. These are usually replaced by EC repeats found in other portions of the PCDH15 protein (Fig. 3C). Importantly, there is no direct way to experimentally distinguish between isoforms that have changes in the extracellular domain as current antibodies were designed to recognize epitopes found within the intracellular domain of PCDH15 (CD1, CD2, or CD3).

The large number of isoforms produced by alternative splicing raises an important question about the biological role of PCDH15 diversity. Within the mature hair cell bundle, PCDH15 is located not only in tip links, but in other linkages such as lateral links and kinocilial links (Fig. 3C). Perhaps it is necessary for many 
variants of PCDH15 to be found in hair cells to maintain diverse connections and to tune bond strength. Interestingly, recent experiments suggest that PCDH15-PCDH15 tip links are formed in mature hair cells shortly after disruption with BAPTA (Indzhykulian et al. 2013). The investigators provided data indicating that such noncanonical PCDH15-PCDH15 tip links are formed transiently, perhaps by two different isoforms of PCDH15, with canonical PCDH15CDH23 tip links reestablished after $\sim 36 \mathrm{~h}$ (Fig. 3E). Regeneration after tip link disruption with BAPTA is thought to mimic normal tip link development and to be a good model for regeneration after noise induced damage (Zhao et al. 1996; Lelli et al. 2010). However, until individual PCDH15 isoforms can be uniquely identified, the precise spatiotemporal expression and composition of hair-cell bundle linkages during normal development and regeneration will remain unknown.

\section{INSIGHT INTO TIP-LINK FUNCTION FROM DISEASE-CAUSING MUTATIONS}

The structural and genetic determinants of CDH23 and PCDH15 function reviewed above have provided a framework to analyze the effect of mutations that alter tip-link function and cause disease. In turn, these analyses have also shed light into the in vivo function of $\mathrm{CDH} 23$ and PCDH15.

A review of the tip link literature indicates that more than 100 missense mutations of the CDH23 extracellular domain (Fig. 2E) are pathogenic and cause deafness (and in some cases vestibular problems), as suggested by segregation and genetic analyses (Bolz et al. 2001; Bork et al. 2001; Astuto et al. 2002; de Brouwer et al. 2003; Pennings et al. 2004; Ouyang et al. 2005; Schultz et al. 2005; Roux et al. 2006; Wagatsuma et al. 2007; Baux et al. 2008; Oshima et al. 2008; Usami et al. 2008; Ammar-Khodja et al. 2009; Shahin et al. 2010; Brownstein et al. 2011; Manji et al. 2011; Roux et al. 2011; Schultz et al. 2011; Bonnet and El-Amraoui 2012; De Keulenaer et al. 2012; Han et al. 2012; Miyagawa et al. 2012, 2013; Ganapathy et al. 2014; Lu et al. 2014; Woo et al. 2014; Atik et al. 2015; Lenar- duzzi et al. 2015; Sloan-Heggen et al. 2015; Abdi et al. 2016; Moteki et al. 2016; Sloan-Heggen et al. 2016). The structural and biochemical effects of some of these mutations have been tested in vitro using the mouse CDH23 EC1-2 fragment, alone and in complex with $\mathrm{PCDH} 15$ EC1-2 (Sotomayor et al. 2010, 2012). For instance, the p.D124G mutation that causes progressive hearing loss in human patients effectively eliminates the side chain of a charged residue that coordinates calcium at the EC1-2 linker. Experiments showed that this mutation does not prevent folding, but rather decreases affinity for calcium, thereby indirectly altering the flexibility and elasticity of the EC1-2 linker.

Disease mutations have also helped to elucidate distinct roles that the $\mathrm{CDH} 23$ and PCDH15 bond may play in mechanotransduction and hair-cell bundle development. A validation of the CDH23 and PCDH15 interaction and its function in mechanotransduction came from the analysis of the PCDH15 p.R139G mutation. In vitro experiments show that the handshake interaction is impaired by this mutation (Kazmierczak et al. 2007; Sotomayor et al. 2012), and genetic analysis show that p.R139G causes deafness in humans (Ahmed et al. 2003, 2008). In experiments in which OHC tip links are ruptured with a calcium chelator and subsequent regeneration is induced through addition of calcium ex vivo, wild-type PCDH15 fragments applied extracellularly blocked tip-link regeneration but fragments carrying the p.R139G mutation did not (as revealed by monitoring recovery of transduction currents) (Lelli et al. 2010). Collectively, these results indicate that the intact heterophilic handshake interaction is required for hair-cell channel gating and mechanotransduction, even in properly developed hair bundles.

In parallel, Noddy mice validated the heterophilic handshake interaction in vivo and also indicated its potential role in both mechanotransduction and hair-cell bundle development (Geng et al. 2013). These mice carry a PCDH15 p.I134N mutation that completely abolishes CDH23 EC1-2 and PCDH15 EC1-2 binding in vitro, and that causes deafness and vestibular dysfunction without mislocalization of PCDH15 
A. Jaiganesh et al.

in vivo. In addition, the Noddy mutation causes significant stereocilia bundle splaying and misplacement of kinocilia, suggesting that the $\mathrm{CDH} 23$ and $\mathrm{PCDH} 15$ handshake interaction might be relevant for bundle development and maintenance as well. It is possible that impaired mechanotransduction leads to bundle degeneration thus explaining the phenotype (VélezOrtega et al. 2017), or that the handshake is required for mechanotransduction as well as bundle development and maintenance (in both cochlear and vestibular hair cells). Sorting out the developmental and transduction roles of the $\mathrm{CDH} 23$ and $\mathrm{PCDH} 15$ interaction may require further analysis of the expression and localization of all the isoforms from each protein in each type of hair cell (cochlear IHC and OHC as well as vestibular) and across different species.

The plethora of $\mathrm{CDH} 23$ and PCDH15 mutations that are pathogenic in humans can also provide insight into their function in different organs. Several missense mutations impair handshake formation, as discussed above, but many others occur throughout the extracellular domain of $\mathrm{CDH} 23$ and PCDH15 and are less likely to impair their binding (Figs. 2E, 3B). It is unclear why more deafness-causing missense mutations are found throughout the extracellular domain of $\mathrm{CDH} 23$ than in PCDH15, but many of them occur at calcium-binding motifs and may impair calcium binding, which would mechanically weaken the tip link (de Brouwer et al. 2003; Sotomayor and Schulten 2008; Schwander et al. 2009; Sotomayor et al. 2010). This may explain why some mutations cause progressive hearing loss but not vestibular dysfunction (p.D124G), as calcium levels in the vestibular system are about one order of magnitude higher than in the cochlea. Intriguingly, nonsense mutations in PCDH15 and $\mathrm{CDH} 23$ result in Usher syndrome, a human disease that affects both hearing and vision (Friedman et al. 2011; Bonnet and El-Amraoui 2012; Mathur and Yang 2015). It has been difficult to correlate defects in PCDH15 and CDH23 to disease phenotype in the eye, as mouse photoreceptors do not express the longest $\mathrm{CDH} 23$ isoform and lack the calyceal processes in which $\mathrm{CDH} 23$ and PCDH15 localize in macaque, frog, and human eyes (Lagziel et al. 2009; Sahly et al. 2012). It is possible that mutations that affect the mechanical properties of $\mathrm{CDH} 23$ and $\mathrm{PCDH} 15$ might be less deleterious for their function in shaping outer segments of photoreceptors (Schietroma et al. 2017) and hence may not result in an Usher syndrome phenotype. However, this hypothesis needs to be tested in animal models that include calyceal processes. Overall, there seems to be a clear correlation between severity of phenotype, organs affected, and the biochemical consequences of mutations causing disease (Sotomayor et al. 2012).

\section{FROM HAIR-CELL BUNDLE MICROMECHANICS TO TIP-LINK NANOMECHANICS AND BACK}

Structural, genetic, biochemical, and biophysical studies of $\mathrm{CDH} 23$ and PCDH15, their various isoforms and their mutant forms, have opened the door to explore the first steps of sensory perception in the inner ear at the molecular level. The exceptional properties of these cadherins, as revealed by partial structures of their unique interacting tips and atypical linkers, highlight the complexity of this system and place constraints on how to interpret and model experiments that test the micromechanics of hair cells. In the simplest model of hair-cell mechanotransduction, the tip link is assumed to withstand and convey physiological forces and to be a soft and extensible spring that directly connects to and gates transduction channels. We critically evaluate this model and explore how to refine and extend it in light of what is known and what needs to be determined regarding the nanomechanics of CDH23 and PCDH15.

\section{How Strong Is the Tip Link?}

Following the discovery of $\mathrm{CDH} 23$ and PCDH15 as proteins that connect tip-to-tip to bridge neighboring stereocilia and form the tip link, it is reasonable to hypothesize that the overall strength of the tip link is determined by the strength of the CDH23-PCDH15 handshake bond (Kazmierczak et al. 2007; Sotomayor et al. 2012). If this interaction is broken, the tip 
link will not convey force to transduction channels. Steered MD simulations that apply force to mimic physiological stretching predict a strong heterodimer bond, with rupture of a single cadherin handshake occurring when the force exceeds $400 \mathrm{pN}$ at a stretching speed of $0.02 \mathrm{~nm} /$ $\mathrm{ns}$ (theoretically estimated to be $\sim 40 \mathrm{pN}$ for very slow stretching) (Evans and Ritchie 1997) and with unbinding occurring before unfolding of EC repeats of known structure when all calcium-binding sites are occupied (Sotomayor et al. 2012). Unbinding before unfolding occurs even when considering the EC9-10 calcium-free linker in simulations of a chimeric complex formed by combining the CDH23 EC1-2 and PCDH15 EC1-2 handshake with the PCDH15 EC8-10 structure (Araya-Secchi et al. 2016). These results suggest that the tip-link handshake bond is the "Achilles' heel" of the transduction apparatus, in which rupture may represent a safety mechanism that protects other components of the system. However, we do not know the local calcium concentration around tip links and the exact affinity of all CDH23 and PCDH15 calcium-binding sites. Unfolding before unbinding may occur under some circumstances when calcium concentration is too low for all sites to be occupied (Sotomayor et al. 2012). In addition, simulation predictions need to be verified experimentally and should incorporate structures of all tip link EC repeats as they become available.

Equilibrium measurements have shown that binding affinity of the $\mathrm{CDH} 23 \mathrm{EC} 1-2$ and PCDH15 EC1-2 dimer complex is $\sim 3 \mu \mathrm{M}$ at $10^{\circ} \mathrm{C}$ in vitro, similar to what has been measured for classical cadherins (Katsamba et al. 2009; Harrison et al. 2010, 2016; Sotomayor et al. 2012). Yet, equilibrium binding affinity is not necessarily a good measure of the mechanical strength of the bond. In addition, parallel homodimerization of each cadherin resulting in a heterotetrameric complex (Kazmierczak et al. 2007) may significantly increase the affinity and mechanical strength of a hypothetical double handshake bond (Sotomayor et al. 2012). Moreover, glycosylation may also play a role in allosterically tuning affinity and strength. Further overlap of EC repeats, as seen in other protocadherin bonds (Cooper et al. 2016;
Goodman et al. 2016; Nicoludis et al. 2016), could provide additional mechanical resistance, but equilibrium binding affinities for EC1-4 homophilic bonds of clustered protocadherins are similar to those involving EC1 to EC1 interactions in classical cadherins (Goodman et al. 2016). Additionally, there is no experimental evidence that further overlap of EC repeats could occur for CDH23 and PCDH15. Measurement or prediction of the tip link unbinding strength must also take into account the time scale of sound mechanotransduction (down to $\sim 50 \mu$ s for a $20-\mathrm{kHz}$ frequency), which would require fast stretching speeds that currently can only be achieved through MD simulations or high-speed atomic force microscopy (Lee et al. 2009; Rico et al. 2013).

\section{Is the Cadherin Tip Link Elastic?}

Inner-ear mechanotransduction models feature a soft spring connected in series with the transduction channel to modulate its force-induced gating (Markin and Hudspeth 1995). The tip link made of $\mathrm{CDH} 23$ and PCDH15 does convey force to the transduction channel (Basu et al. 2016), but does it have the expected elasticity $(\sim 0.5 \mathrm{mN} / \mathrm{m})$ and extensibility (>100 nm for extreme stimuli) (Howard and Hudspeth 1988; Shepherd and Corey 1994; Cheung and Corey 2006) to be the gating spring? Initial $\mathrm{MD}$ simulations of the linear $\mathrm{CDH} 23 \mathrm{EC} 1-2$ structure indicated that canonical $\mathrm{CDH} 23 \mathrm{EC}$ repeats are stiff and unlikely to provide the necessary elasticity (Sotomayor et al. 2010), suggesting that another element in the transduction apparatus might form the gating spring. However, SMD simulations of PCDH15 that include the bent EC9-10 linker indicate that unbending results in a soft elastic behavior. Moreover, simulations of the chimeric $\mathrm{CDH} 23 \mathrm{EC} 1-2$ and PCDH15 EC1-2 handshake with PCDH15 EC8-10 predict that unbending occurs before unbinding (Araya-Secchi et al. 2016), further emphasizing the role that unbending of EC repeats can play in mechanotransduction (Fig. 4).

In simulations of the chimeric complex formed by CDH23 EC1-2 and PCDH15 EC1$2+8-10$ at the slowest pulling speed tested 
A. Jaiganesh et al.

$(0.1 \mathrm{~nm} / \mathrm{ns})$, the effective spring constant during unbending was $\sim 8 \mathrm{mN} / \mathrm{m}$ with a combined extension of $\sim 5 \mathrm{~nm}$ (Araya-Secchi et al. 2016). Given a $10 \mathrm{pN}$ resting tension in the tip link (Jaramillo and Hudspeth 1993), a lower limit for the effective equilibrium spring constant would be $\sim 10 \mathrm{pN} / 5 \mathrm{~nm}=2 \mathrm{mN} / \mathrm{m}$. Similarly, a set of bent EC repeats in series ("accordion model" in Fig. 4D) could behave as a soft spring, with $8 \mathrm{EC}$ repeats in such a conformation having an effective equilibrium spring constant of 10 $\mathrm{pN} /(2.7 \times 4 \mathrm{~nm}) \sim 1 \mathrm{mN} / \mathrm{m}$, a value that is close to that expected for the gating spring. Although sequence analyses indicate that there are other EC repeats in $\mathrm{CDH} 23$ and $\mathrm{PCDH} 15$ with atypical linkers that might be flexible (Fig. 4A), there are currently no other structures showing bent linkers in the tip link. In addition, the role played by unbending has not been tested in vivo, and maximum extensibility in the accordion model is limited to $\sim 10 \mathrm{~nm}$ per $8 \mathrm{EC}$ repeats, although experiments suggest that if tip links' attachments to the cytoskeleton do not slip, extreme stimuli can extend them by $>100 \mathrm{~nm}$ without altering transduction (Shepherd and Corey 1994).

Other sources of elasticity and extensibility for the tip link include emergent properties from parallel (cis) dimerization ("scissor elevator" model), sliding of overlapped regions in $\mathrm{CDH} 23$ and PCDH15, and unfolding of weak EC repeats (Fig. 4A,B,D). In the "scissor elevator" model, rearrangement of dimer components in each molecule could provide some elasticity. Images of the complete extracellular domains of CDH23 and PCDH15 by negative staining transmission electron microscopy indicate heterogeneity of conformations supporting this model (Kazmierczak et al. 2007), but these rearrangements are unlikely to result in much extension unless significant bending of EC repeats occurs. The sliding of overlapped $\mathrm{CDH} 23$ and PCDH15 tips could provide elasticity and some notable extensibility depending on the degree of overlap, but so far there is no evidence that overlap goes beyond EC1-2 for this complex, and beyond EC1-4 in other vertebrate cadherins (Tsukasaki et al. 2014; Cooper et al. 2016; Goodman et al. 2016; Nicoludis et al. 2016). Complete or partial unfolding of EC re- peats could provide significant extensibility for the tip link $(\sim 100$ residues $\times 3.8 \AA-4.5 \mathrm{~nm}=$ $33.5 \mathrm{~nm}$ per unfolded repeat), adding a soft entropic elastic response caused by the unfolded polypeptide $\left(3 k_{\mathrm{B}} T / n l^{2} \sim 0.9 \mathrm{mN} / \mathrm{m}\right.$ per unfolded repeat for small forces at room temperature, with $n=100$ amino acids and the length of an amino acid set to $l=3.8 \AA$ ). However, refolding of EC repeats may take milliseconds and be incompatible with the time scale of fast mechanotransduction (hundreds of microseconds) and, so far, unfolding is not predicted to occur before unbinding of the dimeric handshake bond.

Although the tip link displays some of the soft elastic behavior expected for the gating spring, other parts of the mechanotransduction apparatus may contribute elasticity and extensibility as well. Proteins that connect PCDH15 to the transduction channel, or those that connect the transduction channel or $\mathrm{CDH} 23$ to the cytoskeleton might have the ideal properties (Fig. 4B), but we know little about the architecture of the transduction complex. Furthermore, the lipid bilayer that surrounds the channel could provide soft elasticity (Powers et al. 2012, 2014; Kim 2015; Peng et al. 2016), and significant extensibility if membrane tethers are formed (Li et al. 2002). Whether membrane tether formation can occur before unbinding of PCDH15 from $\mathrm{CDH} 23$ needs to be determined with more complete in vitro and in silico models of the transduction apparatus. An interesting and feasible model that is compatible with all experimental data available would have unbending of the calcium-free PCDH15 EC linkers as the source of elasticity with limited extensibility for physiological gating spring function (ArayaSecchi et al. 2016), and either unfolding, slippage of the CDH23 attachment to the cytoskeleton, or membrane tether formation explaining the large extensions indirectly estimated for extreme nonphysiological stimuli (Shepherd and Corey 1994).

How is Mechanical Force Conveyed to Other Components of the Transduction Machinery?

The exact molecular composition of the transduction channel and its linkage to PCDH15 re- 

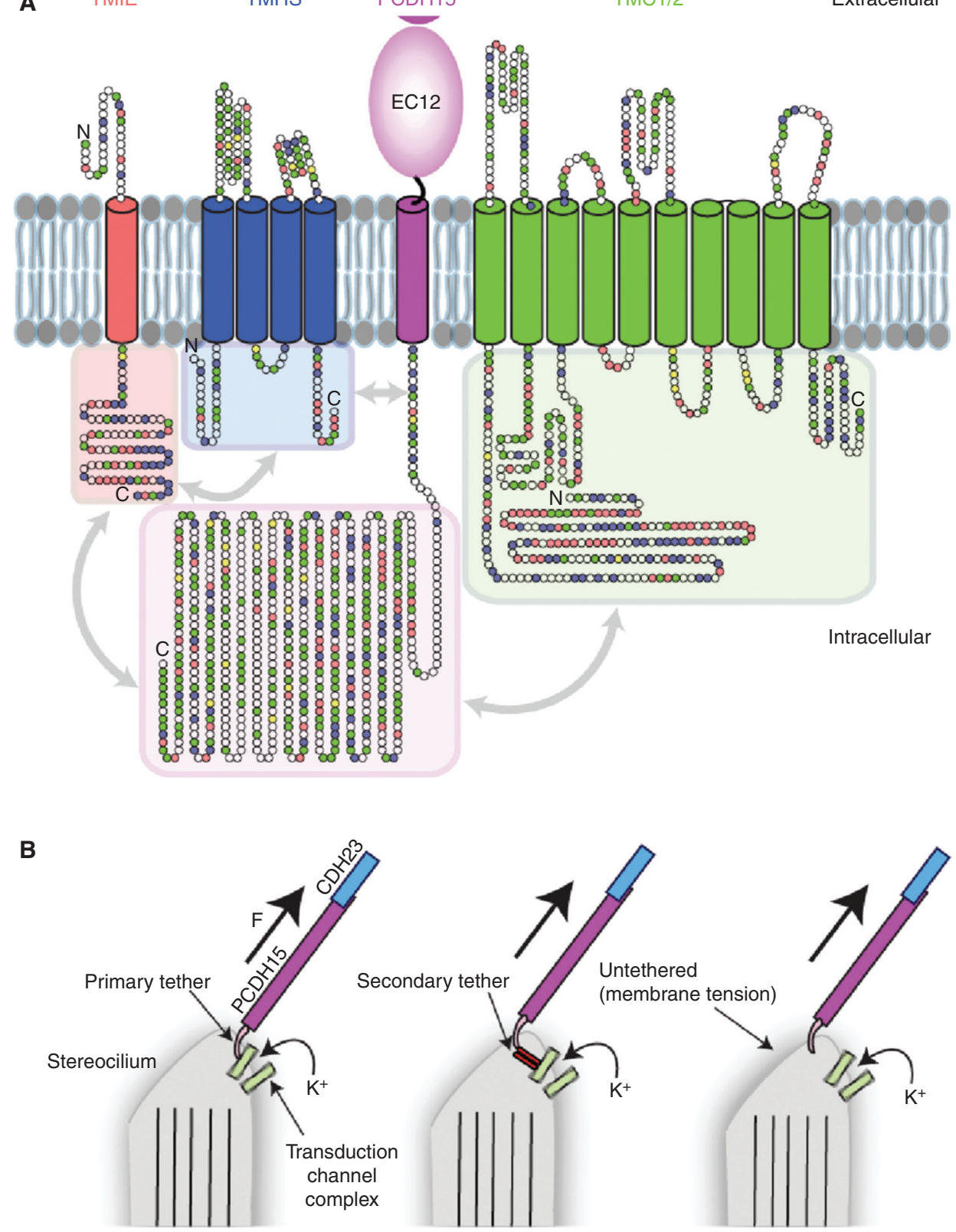

Figure 5. Protocadherin-15 (PCDH15) and the hair-cell mechnotransduction apparatus. (A) Putative assembly of membrane components involved in mechanotransduction near PCDH15. Circles represent residues colored by property (positive, blue; negative, red; polar, green; hydrophobic, white; cysteine, yellow). Gray arrows indicated experimentally suggested (isoform-dependent) interactions between membrane components. $(B)$ Three models of force transmission by tip links. In the first model, PCDH15 directly connects to the transduction channel complex, whereas in the second and third models force is conveyed through accessory proteins or the membrane bilayer. 
A. Jaiganesh et al.

mains unknown. The transmembrane proteins TMIE, TMHS, and TMC1/2 have all been shown to be integral components of the transduction apparatus (Fig. 5A), but structural details remain elusive. Identification of the pore forming subunit and how the transduction machinery assembles remain controversial (Kawashima et al. 2011; Xiong et al. 2012; Pan et al. 2013; Zhao et al. 2014; Beurg et al. 2015a, 2016; Effertz et al. 2015; Kurima et al. 2015; Corey and Holt 2016; Fettiplace 2016; Wu and Muller 2016; Wu et al. 2016; Erickson et al. 2017; Cunningham et al. 2017). There is evidence that PCDH15 interacts directly with TMIE and TMC1/2 (Zhao et al. 2014; Beurg et al. 2015b; Maeda et al. 2014, 2017), which would favor a model in which force is directly conveyed to the transduction channel by the tip link via PCDH15, or at least through an accessory membrane protein connected to PCDH15 (Fig. 5B).

In an alternative scenario, PCDH15 could convey force indirectly by stretching the membrane around it, thereby activating mechanosensitive channels gated by membrane tension, similar to Piezo proteins in eukaryotes and MscS and MscL in bacteria (Kung et al. 2010; Coste et al. 2012; Anishkin et al. 2014; Syeda et al. 2016). There is some evidence that lipids are involved in transduction channel adaptation, whereby transduction currents decay in the presence of sustained stimulation (Eatock et al. 1987; Holt et al. 2002). However, the molecular mechanisms of adaptation are controversial (Peng et al. 2013, 2016; Corns et al. 2014; Berger and Hudspeth 2017) and whether membrane tension plays a role in hair-cell channel gating and adaptation needs to be experimentally verified (Powers et al. 2012, 2014; Kim 2015).

\section{CONCLUDING REMARKS: BEYOND INNER-EAR HAIR-CELL MECHANOTRANSDUCTION}

Multiple experiments have shown that tip links in rodent cochlear and vestibular hair cells are formed by $\mathrm{CDH} 23$ and $\mathrm{PCDH} 15$, with additional evidence supporting this model for human, fish, and avian tip links (Siemens et al. 2004; Söllner et al. 2004; Ahmed et al. 2006;
Kazmierczak et al. 2007; Goodyear et al. 2010; Alagramam et al. 2011). The nature of the mechanical stimuli in the senses of hearing and balance is very different, and perhaps various splice isoforms might be differentially used to respond to sound (low and high frequency) and vestibular stimuli (low frequency). The use of various protein isoforms and even the protein composition of the tip link may vary in other species such as amphibian and reptiles, for which the CDH23 and PCDH15 tip-link model has not been thoroughly probed. Even less is known about tip links in hair-cell-like receptors found in the statocyst of octopuses, on the velum and tentacles of jellyfish, and on the oral area of tunicate (Burighel et al. 2011; Duncan and Fritzsch 2012; Manley et al. 2012; Manley 2017). A thorough comparison of tip links from diverse species and an investigation of the molecular evolution of $\mathrm{CDH} 23$ and PCDH15 (Shen et al. 2012; Lambert et al. 2017) may provide further information about tip link function in organs that respond to diverse mechanical stimuli.

$\mathrm{CDH} 23$ and PCDH15 are unique members of the cadherin superfamily. Their overall architecture, heterophilic interaction, and noncanonical linkers in their extracellular domains contrast with the more uniform structural characteristics of the clustered protocadherins and the classical and desmosomal cadherins. The unique properties of $\mathrm{CDH} 23$ and PCDH15 might have been acquired throughout evolution to perform their specific function in inner ear mechanotransduction. Similarly, several nonclassical, nonclustered members of the superfamily feature distinct extracellular domains and might be involved in functions that go beyond cell-cell adhesion. PCDH21 in photoreceptors, PCDH24 and CDHR5 in the gut epithelium, and the giant FAT and DCHS cadherins implicated in regulation of cell polarity and proliferation seem to have adopted similar strategies to acquire function by varying their extracellular linkers. Sequence analyses predict several noncanonical linkers in these proteins that may bend or be flexible as observed in PCDH15 (Jin et al. 2012; Araya-Secchi et al. 2016; Powers et al. 2017). Interestingly, electron 
microscopy studies of FAT and DCHS show multiple bends along their extracellular domain (Tsukasaki et al. 2014), consistent with lack of calcium-binding motifs at linkers as predicted. The lack of a common sequence motif among these calcium-free linkers suggests that they could provide a variety of conformations and play diverse roles in cadherin function (Jin et al. 2012), including changing their mechanical properties. Exploring the architecture, biophysics, and evolution of nonclassical, nonclustered members of the superfamily may help elucidate the mechanisms underlying their normal function and their role in disease (Redies et al. 2012; Hirabayashi and Yagi 2014).

\section{ACKNOWLEDGMENTS}

We thank members of our group for discussions and support, as well as Carien M. Niessen, David P. Corey, and Thomas B. Friedman for their feedback. M.S. laboratory is supported by grants from the National Institutes of Health (NIDCD R00 DC012534 and R01 DC015271). M.S. is an Alfred P. Sloan Fellow (FR-2015-65794).

\section{REFERENCES}

Abdi S, Bahloul A, Behlouli A, Hardelin JP, Makrelouf M, Boudjelida K, Louha M, Cheknene A, Belouni R, Rous Y, et al. 2016. Diversity of the genes implicated in Algerian patients affected by Usher syndrome. PLoS ONE 11: e0161893.

Ahmed ZM, Riazuddin S, Bernstein SL, Ahmed Z, Khan S, Griffith AJ, Morell RJ, Friedman TB, Riazuddin S, Wilcox ER. 2001. Mutations of the protocadherin gene PCDH15 cause Usher syndrome type 1F. Am J Hum Genet 69: 25-34.

Ahmed ZM, Riazuddin S, Ahmad J, Bernstein SL, Guo Y, Sabar MF, Sieving P, Riazuddin S, Griffith AJ, Friedman TB, et al. 2003. PCDH15 is expressed in the neurosensory epithelium of the eye and ear and mutant alleles are responsible for both USH1F and DFNB23. Hum Mol Genet 12: 3215-3223.

Ahmed ZM, Goodyear R, Riazuddin S, Lagziel A, Legan PK, Behra M, Burgess SM, Lilley KS, Wilcox ER, Riazuddin S, et al. 2006. The tip-link antigen, a protein associated with the transduction complex of sensory hair cells, is protocadherin-15. J Neurosci 26: 7022-7034.

Ahmed ZM, Riazuddin S, Aye S, Ali RA, Venselaar H, Anwar S, Belyantseva PP, Qasim M, Riazuddin S, Friedman TB. 2008. Gene structure and mutant alleles of PCDH15: Nonsyndromic deafness DFNB23 and type 1 Usher syndrome. Hum Genet 124: 215-223.
Alagramam KN, Murcia CL, Kwon HY, Pawlowski KS, Wright CG, Woychik RP. 2001a. The mouse Ames waltzer hearing-loss mutant is caused by mutation of $P c d h 15$, a novel protocadherin gene. Nat Genet 27: 99-102.

Alagramam KN, Yuan H, Kuehn MH, Murcia CL, Wayne S, Srisailpathy CR, Lowry RB, Knaus R, Van Laer L, Bernier FP, et al. 2001b. Mutations in the novel protocadherin PCDH15 cause Usher syndrome type 1F. Hum Mol Genet 10: 1709-1718.

Alagramam KN, Goodyear RJ, Geng R, Furness DN, van Aken AFJ, Marcotti W, Kros CJ, Richardson GP. 2011. Mutations in protocadherin 15 and cadherin 23 affect tip links and mechanotransduction in mammalian sensory hair cells. PLoS ONE 6: e19183.

Ammar-Khodja F, Faugère V, Baux D, Giannesini C, Léonard S, Makrelouf M, Malek R, Djennaoui D, Zenati A, Claustres M, et al. 2009. Molecular screening of deafness in Algeria: High genetic heterogeneity involving DFNB1 and the Usher loci, DFNB2/USH1B, DFNB12/USH1D and DFNB23/USH1F. Eur J Med Genet 52: 174-179.

Angelaki DE, Cullen KE. 2008. Vestibular system: The many facets of a multimodal sense. Annu Rev Neurosci 31: $125-150$.

Anishkin A, Loukin SH, Teng J, Kung C. 2014. Feeling the hidden mechanical forces in lipid bilayer is an original sense. Proc Natl Acad Sci 111: 7898-7905.

Araya-Secchi R, Neel BL, Sotomayor M. 2016. An elastic element in the protocadherin-15 tip link of the inner ear. Nat Commun 7: 13458.

Assad JA, Shepherd GM, Corey DP. 1991. Tip-link integrity and mechanical transduction in vertebrate hair cells. Neuron 7: 985-994.

Astuto LM, Bork JM, Weston MD, Askew JW, Fields RR, Orten DJ, Ohliger SJ, Riazuddin S, Morell RJ, Khan S, et al. 2002. $C D H 23$ mutation and phenotype heterogeneity: A profile of 107 diverse families with Usher syndrome and nonsyndromic deafness. Am J Hum Genet 71: 262-275.

Atik T, Onay H, Aykut A, Bademci G, Kirazli T, Tekin M, Ozkinay F. 2015. Comprehensive analysis of deafness genes in families with autosomal recessive nonsyndromic hearing loss. PLoS ONE 10: e0142154.

Bahloul A, Michel V, Hardelin JP, Nouaille S, Hoos S, Houdusse A, England P, Petit C. 2010. Cadherin-23, myosin VIIa and harmonin, encoded by Usher syndrome type I genes, form a ternary complex and interact with membrane phospholipids. Hum Mol Genet 19: 3557-3565.

Basu A, Lagier S, Vologodskaia M, Fabella BA, Hudspeth AJ. 2016. Direct mechanical stimulation of tip links in hair cells through DNA tethers. Elife 5: e16041.

Baux D, Faugère V, Larrieu L, Le Guédard-Méreuze S, Hamroun D, Béroud C, Malcolm S, Claustres M, Roux A-F 2008. UMD-USHbases: A comprehensive set of databases to record and analyse pathogenic mutations and unclassified variants in seven Usher syndrome causing genes. Hum Mutat 29: E76-E87.

Belyantseva IA, Boger ET, Friedman TB. 2003. Myosin XVa localizes to the tips of inner ear sensory cell stereocilia and is essential for staircase formation of the hair bundle. Proc Natl Acad Sci 100: 13958-13963.

Belyantseva IA, Boger ET, Naz S, Frolenkov GI, Sellers JR, Ahmed ZM, Griffith AJ, Friedman TB. 2005. Myosin$\mathrm{XVa}$ is required for tip localization of whirlin and differ- 
A. Jaiganesh et al.

ential elongation of hair-cell stereocilia. Nat Cell Biol 7: 148-156.

Berger F, Hudspeth AJ. 2017. Chemomechanical regulation of myosin Ic cross-bridges: Deducing the elastic properties of an ensemble from single-molecule mechanisms ed. A.D. McCulloch. PLOS Comput Biol 13: e1005566.

Bertolotti R, Rutishauser U, Edelman GM. 1980. A cell surface molecule involved in aggregation of embryonic liver cells. Proc Natl Acad Sci 77: 4831-4835.

Beurg M, Fettiplace R, Nam JH, Ricci AJ. 2009. Localization of inner hair cell mechanotransducer channels using high-speed calcium imaging. Nat Neurosci 12: 553-558.

Beurg M, Goldring AC, Fettiplace R. 2015a. The effects of Tmcl Beethoven mutation on mechanotransducer channel function in cochlear hair cells. J Gen Physiol 146: $233-243$.

Beurg M, Xiong W, Zhao B, Müller U, Fettiplace R. 2015b. Subunit determination of the conductance of hair-cell mechanotransducer channels. Proc Natl Acad Sci 112: 1589-1594.

Beurg M, Goldring AC, Ricci AJ, Fettiplace R. 2016. Development and localization of reverse-polarity mechanotransducer channels in cochlear hair cells. Proc Natl Acad Sci 113: 6767-6772.

Boëda B, El-Amraoui A, Bahloul A, Goodyear R, Daviet L, Blanchard S, Perfettini I, Fath KR, Shorte S, Reiners J, et al. 2002. Myosin VIIa, harmonin and cadherin 23, three Usher I gene products that cooperate to shape the sensory hair cell bundle. EMBO J 21: 6689-6699.

Boggon TJ, Murray J, Chappuis-Flament S, Wong E, Gumbiner BM, Shapiro L. 2002. C-cadherin ectodomain structure and implications for cell adhesion mechanisms. Science 296: 1308-1313.

Bolz H, von Brederlow B, Ramírez A, Bryda EC, Kutsche K, Nothwang HG, Seeliger M, del C-Salcedó Cabrera M, Vila MC, Molina OP, et al. 2001. Mutation of $\mathrm{CDH} 23$, encoding a new member of the cadherin gene family, causes Usher syndrome type 1D. Nat Genet 27: 108-112.

Bonnet C, El-Amraoui A. 2012. Usher syndrome (sensorineural deafness and retinitis pigmentosa). Curr Opin Neurol 25: 42-49.

Bork JM, Peters LM, Riazuddin S, Bernstein SL, Ahmed ZM, Ness SL, Polomeno R, Ramesh A, Schloss M, Srisailpathy CR, et al. 2001. Usher syndrome $1 \mathrm{D}$ and nonsyndromic autosomal recessive deafness DFNB12 are caused by allelic mutations of the novel cadherin-like gene $\mathrm{CDH} 23$. Am J Hum Genet 68: 26-37.

Bosher SK, Warren RL. 1978. Very low calcium content of cochlear endolymph, an extracellular fluid. Nature 273: 377-378.

Brasch J, Harrison OJ, Honig B, Shapiro L. 2012. Thinking outside the cell: How cadherins drive adhesion. Trends Cell Biol 22: 299-310.

Brownstein Z, Friedman LM, Shahin H, Oron-Karni V, Kol N, Abu Rayyan A, Parzefall T, Lev D, Shalev S, Frydman M, et al. 2011. Targeted genomic capture and massively parallel sequencing to identify genes for hereditary hearing loss in Middle Eastern families. Genome Biol 12: R89.

Burgoyne T, Meschede IP, Burden JJ, Bailly M, Seabra MC Futter CE. 2015. Rod disc renewal occurs by evagination of the ciliary plasma membrane that makes cadherin- based contacts with the inner segment. Proc Natl Acad Sci 112: 15922-15927.

Burighel P, Caicci F, Manni L. 2011. Hair cells in non-vertebrate models: Lower chordates and molluscs. Hear Res 273: 14-24.

Cailliez F, Lavery R. 2005. Cadherin mechanics and complexation: The importance of calcium binding. Biophys J 89: 3895-3903.

Ceriani F, Mammano F. 2012. Calcium signaling in the cochlea-Molecular mechanisms and physiopathological implications. Cell Commun Signal 10: 20.

Cheung ELM, Corey DP. 2006. $\mathrm{Ca}^{2+}$ changes the force sensitivity of the hair-cell transduction channel. Biophys J 90: 124-139.

Cooper SR, Jontes JD, Sotomayor M. 2016. Structural determinants of adhesion by Protocadherin-19 and implications for its role in epilepsy. Elife 5: e18529.

Corey DP. 2007. Stringing the fiddle: The inner ear's twopart invention. Nat Neurosci 10: 1232-1233.

Corey DP, Holt JR. 2016. Are TMCs the mechanotransduction channels of vertebrate hair cells? J Neurosci 36: 10921-10926.

Corey DP, Howard J. 1994. Models for ion channel gating with compliant states. Biophys J 66: 1254-1257.

Corey DP, Hudspeth AJ. 1983. Kinetics of the receptor current in bullfrog saccular hair cells. J Neurosci 3: 962-976.

Corns LF, Johnson SL, Kros CJ, Marcotti W. 2014. Calcium entry into stereocilia drives adaptation of the mechanoelectrical transducer current of mammalian cochlear hair cells. Proc Natl Acad Sci 111: 14918-14923.

Coste B, Xiao B, Santos JS, Syeda R, Grandl J, Spencer KS, Kim SE, Schmidt M, Mathur J, Dubin AE, et al. 2012. Piezo proteins are pore-forming subunits of mechanically activated channels. Nature 483: 176-181.

Crawley SW, Shifrin DA, Grega-Larson NE, McConnell RE, Benesh AE, Mao S, Zheng Y, Zheng QY, Nam KT, Millis $\mathrm{BA}$, et al. 2014. Intestinal brush border assembly driven by protocadherin-based intermicrovillar adhesion. Cell 157: 433-446.

Cunningham CL, Wu Z, Jafari A, Zhao B, Schrode K, Harkins-Perry S, Lauer A, Müller U. 2017. The murine catecholamine methyltransferase mTOMT is essential for mechanotransduction by cochlear hair cells. Elife $\mathbf{6}$ : e24318.

Davis H. 1965. A model for transducer action in the cochlea. Cold Spring Harb Symp Quant Biol 30: 181-190.

de Brouwer APM, Pennings RJE, Roeters M, Van Hauwe P, Astuto LM, Hoefsloot LH, Huygen PLM, van den Helm B, Deutman AF, Bork JM, et al. 2003. Mutations in the calcium-binding motifs of $\mathrm{CDH} 23$ and the 35 delG mutation in GJB2 cause hearing loss in one family. Hum Genet 112: 156-163.

De Keulenaer S, Hellemans J, Lefever S, Renard J-P, De Schrijver J, Van de Voorde H, Tabatabaiefar M, Van Nieuwerburgh F, Flamez D, Pattyn F, et al. 2012. Molecular diagnostics for congenital hearing loss including 15 deafness genes using a next generation sequencing platform. BMC Med Genomics 5: 17.

DeRosier DJ, Tilney LG, Egelman E. 1980. Actin in the inner ear: The remarkable structure of the stereocilium. Nature 287: 291-296. 
Di Palma F, Holme RH, Bryda EC, Belyantseva IA, Pellegrino R, Kachar B, Steel KP, Noben-Trauth K. 2001a. Mutations in Cdh23, encoding a new type of cadherin cause stereocilia disorganization in waltzer, the mouse model for Usher syndrome type 1D. Nat Genet 27: 103-107.

Di Palma F, Pellegrino R, Noben-Trauth K. 2001b. Genomic structure, alternative splice forms and normal and mutant alleles of cadherin 23 (Cdh23). Gene 281: 31-41.

Duncan JS, Fritzsch B. 2012. Evolution of sound and balance perception: Innovations that aggregate single hair cells into the ear and transform a gravistatic sensor into the organ of corti. Anat Rec Adv Integr Anat Evol Biol 295: 1760-1774.

Eatock RA, Songer JE. 2011. Vestibular hair cells and afferents: Two channels for head motion signals. Annu Rev Neurosci 34: 501-534.

Eatock RA, Corey DP, Hudspeth AJ. 1987. Adaptation of mechanoelectrical transduction in hair cells of the bullfrog's sacculus. J Neurosci 7: 2821-2836.

Effertz T, Scharr AL, Ricci AJ. 2015. The how and why of identifying the hair cell mechano-electrical transduction channel. Pflügers Arch Eur J Physiol 467: 73-84.

Elledge HM, Kazmierczak P, Clark P, Joseph JS, Kolatkar A Kuhn P, Müller U. 2010. Structure of the N terminus of cadherin 23 reveals a new adhesion mechanism for a subset of cadherin superfamily members. Proc Natl Acad Sci 107: 10708-10712.

Erickson T, Morgan CP, Olt J, Hardy K, Busch-Nentwich E, Maeda R, Clemens R, Krey JF, Nechiporuk A, BarrGillespie PG, et al. 2017. Integration of Tmc1/2 into the mechanotransduction complex in zebrafish hair cells is regulated by Transmembrane O-methyltransferase (Tomt). Elife 6: e28474.

Evans E, Ritchie K. 1997. Dynamic strength of molecular adhesion bonds. Biophys J 72: 1541-1555.

Fettiplace R. 2016. Is TMC1 the hair cell mechanotransducer channel? Biophys J 111: 3-9.

Fettiplace R, Kim KX. 2014. The physiology of mechanoelectrical transduction channels in hearing. Physiol Rev 94: 951-986.

Flock A, Cheung HC. 1977. Actin filaments in sensory hairs of inner ear receptor cells. J Cell Biol 75: 339-343.

Friedman TB, Schultz JM, Ahmed ZM, Tsilou ET, Brewer CC. 2011. Usher Syndrome: Hearing Loss with Vision Loss. In Medical genetics in the clinical practice of ORL (ed. Alford RL, Sutton VR), Vol. 70, pp. 56-65, Karger, Basel, Switzerland.

Furness DN, Katori Y, Nirmal Kumar B, Hackney CM. 2008. The dimensions and structural attachments of tip links in mammalian cochlear hair cells and the effects of exposure to different levels of extracellular calcium. Neuroscience 154: 10-21.

Ganapathy A, Pandey N, Srisailapathy CRS, Jalvi R, Malhotra V, Venkatappa M, Chatterjee A, Sharma M, Santhanam R, Chadha S, et al. 2014. Non-syndromic hearing impairment in India: High allelic heterogeneity among mutations in TMPRSS3, TMC1, USHIC, CDH23 and TMIE. PLOS ONE 9: e84773.

Geng R, Sotomayor M, Kinder KJ, Gopal SR, Gerka-Stuyt J, Chen DH-C, Hardisty-Hughes RE, Ball G, Parker A, Gaudet R, et al. 2013. Noddy, a mouse harboring a missense mutation in protocadherin-15, reveals the impact of disrupting a critical interaction site between tip-link cadherins in inner ear hair cells. J Neurosci 33: 4395-4404.

Gillespie PG, Müller U. 2009. Mechanotransduction by hair cells: Models, molecules, and mechanisms. Cell 139: 33-44.

Goodman KM, Rubinstein R, Thu CA, Bahna F, Mannepalli S, Ahlsén G, Rittenhouse C, Maniatis T, Honig B, Shapiro L. 2016. Structural basis of diverse homophilic recognition by clustered $\alpha$ - and $\beta$-protocadherins. Neuron 90: 709-723.

Goodyear RJ, Richardson GP. 2003. A novel antigen sensitive to calcium chelation that is associated with the tip links and kinocilial links of sensory hair bundles. J Neurosci 23: 4878-4887.

Goodyear RJ, Legan PK, Wright MB, Marcotti W, Oganesian A, Coats SA, Booth CJ, Kros CJ, Seifert RA, Bowen-Pope DF, et al. 2003. A receptor-like inositol lipid phosphatase is required for the maturation of developing cochlear hair bundles. J Neurosci 23: 9208-9219.

Goodyear RJ, Forge A, Legan PK, Richardson GP. 2010. Asymmetric distribution of cadherin 23 and protocadherin 15 in the kinocilial links of avian sensory hair cells. J Comp Neurol 518: 4288-4297.

Grossman SR, Shlyakhter I, Karlsson EK, Byrne EH, Morales S, Frieden G, Hostetter E, Angelino E, Garber M, Zuk O, et al. 2010. A composite of multiple signals distinguishes causal variants in regions of positive selection. Science 327: 883-886.

Hackney CM, Furness DN, Adato A, Lefèvre G, Delprat B, Michel V, Michalski N, Chardenoux S, Weil D, ElAmraoui A, et al. 2013. The composition and role of cross links in mechanoelectrical transduction in vertebrate sensory hair cells. J Cell Sci 126: 1721-1731.

Han F, Yu H, Tian C, Chen HE, Benedict-Alderfer C, Zheng Y, Wang Q, Han X, Zheng QY. 2012. A new mouse mutant of the $C d h 23$ gene with early-onset hearing loss facilitates evaluation of otoprotection drugs. Pharmacogenomics J 12: 30-44.

Harrison OJ, Bahna F, Katsamba PS, Jin X, Brasch J, Vendome J, Ahlsen G, Carroll KJ, Price SR, Honig B, et al. 2010. Two-step adhesive binding by classical cadherins. Nat Struct Mol Biol 17: 348-357.

Harrison OJ, Brasch J, Lasso G, Katsamba PS, Ahlsen G, Honig B, Shapiro L. 2016. Structural basis of adhesive binding by desmocollins and desmogleins. Proc Natl Acad Sci 113: 7160-7165.

Hatta K, Okada TS, Takeichi M. 1985. A monoclonal antibody disrupting calcium-dependent cell-cell adhesion of brain tissues: Possible role of its target antigen in animal pattern formation. Proc Natl Acad Sci 82: 2789-2793.

Hirabayashi T, Yagi T. 2014. Protocadherins in neurological diseases. Adv Neurobiol 8: 293-314.

Hirano S, Takeichi M. 2012. Cadherins in brain morphogenesis and wiring. Physiol Rev 92: 597-634.

Holt JR, Gillespie SKH, Provance DW, Shah K, Shokat KM, Corey DP, Mercer JA, Gillespie PG. 2002. A chemicalgenetic strategy implicates myosin-1c in adaptation by hair cells. Cell 108: 371-381.

Howard J, Hudspeth AJ. 1988. Compliance of the hair bundle associated with gating of mechanoelectrical transduc- 
A. Jaiganesh et al.

tion channels in the bullfrog's saccular hair cell. Neuron 1: 189-199.

Howard J, Spudich JA. 1996. Is the lever arm of myosin a molecular elastic element? Proc Natl Acad Sci 93: 44624464.

Hudspeth AJ. 1985. The cellular basis of hearing: The biophysics of hair cells. Science 230: 745-752.

Hudspeth AJ, Corey DP. 1977. Sensitivity, polarity, and conductance change in the response of vertebrate hair cells to controlled mechanical stimuli. Proc Natl Acad Sci 74: 2407-2411.

Hulpiau P, van Roy F. 2011. New insights into the evolution of metazoan cadherins. Mol Biol Evol 28: 647-57.

Indzhykulian AA, Stepanyan R, Nelina A, Spinelli KJ, Ahmed ZM, Belyantseva IA, Friedman TB, Barr-Gillespie PG, Frolenkov GI. 2013. Molecular remodeling of tip links underlies mechanosensory regeneration in auditory hair cells. PLoS Biol 11: e1001583.

Jaramillo F, Hudspeth AJ. 1993. Displacement-clamp measurement of the forces exerted by gating springs in the hair bundle. Proc Natl Acad Sci 90: 1330-1334.

Jin X, Walker MA, Felsövályi K, Vendome J, Bahna F, Mannepalli S, Cosmanescu F, Ahlsen G, Honig B, Shapiro L. 2012. Crystal structures of Drosophila N-cadherin ectodomain regions reveal a widely used class of $\mathrm{Ca}^{2+}$-free interdomain linkers. Proc Natl Acad Sci 109: E127-E134.

Junghans D, Haas IG, Kemler R. 2005. Mammalian cadherins and protocadherins: about cell death, synapses and processing. Curr Opin Cell Biol 17: 446-452.

Kachar B, Parakkal M, Kurc M, Zhao Yd, Gillespie PG. 2000. High-resolution structure of hair-cell tip links. Proc Natl Acad Sci 97: 13336-13341.

Katsamba P, Carroll K, Ahlsen G, Bahna F, Vendome J, Posy S, Rajebhosale M, Price S, Jessell TM, Ben-Shaul A, et al. 2009. Linking molecular affinity and cellular specificity in cadherin-mediated adhesion. Proc Natl Acad Sci 106: 11594-11599.

Kawashima Y, Géléoc GSG, Kurima K, Labay V, Lelli A, Asai Y, Makishima T, Wu DK, Della Santina CC, Holt JR, et al. 2011. Mechanotransduction in mouse inner ear hair cells requires transmembrane channel-like genes. J Clin Invest 121: 4796-4809.

Kazmierczak P, Sakaguchi H, Tokita J, Wilson-Kubalek EM, Milligan RA, Müller U, Kachar B. 2007. Cadherin 23 and protocadherin 15 interact to form tip-link filaments in sensory hair cells. Nature 449: 87-91.

Kemler R, Babinet C, Eisen H, Jacob F. 1977. Surface antigen in early differentiation. Proc Natl Acad Sci 74: 4449-4452.

Kim J. 2015. Unconventional mechanics of lipid membranes: A potential role for mechanotransduction of hair cell stereocilia. Biophys J 108: 610-621.

Kraemer A, Yap AS. 2003. Coupling adhesion to actin bundles in the inner ear. Novel functions for novel cadherins. EMBO Rep 4: 244-245.

Kung C, Martinac B, Sukharev S. 2010. Mechanosensitive channels in microbes. Annu Rev Microbiol 64: 313-329.

Kurima K, Ebrahim S, Pan B, Sedlacek M, Sengupta P, Millis BA, Cui R, Nakanishi H, Fujikawa T, Kawashima Y, et al. 2015. TMC1 and TMC2 localize at the site of mechanotransduction in mammalian inner ear hair cell stereocilia. Cell Rep 12: 1606-1617.
Lagziel A, Ahmed ZM, Schultz JM, Morell RJ, Belyantseva IA, Friedman TB. 2005. Spatiotemporal pattern and isoforms of cadherin 23 in wild type and waltzer mice during inner ear hair cell development. Dev Biol 280: 295-306.

Lagziel A, Overlack N, Bernstein SL, Morell RJ, Wolfrum U, Friedman TB. 2009. Expression of cadherin 23 isoforms is not conserved: Implications for a mouse model of Usher syndrome type 1D. Mol Vis 15: 1843-1857.

Lambert MJ, Nevue AA, Portfors C V. 2017. Contrasting patterns of adaptive sequence convergence among echolocating mammals. Gene 605: 1-4.

Lee EH, Hsin J, Sotomayor M, Comellas G, Schulten K. 2009. Discovery through the computational microscope. Structure 17: 1295-1306.

Lelli A, Kazmierczak P, Kawashima Y, Müller U, Holt JR. 2010. Development and regeneration of sensory transduction in auditory hair cells requires functional interaction between cadherin-23 and protocadherin-15. J Neurosci 30: 11259-11269.

Lenarduzzi S, Vozzi D, Morgan A, Rubinato E, D'Eustacchio A, Osland TM, Rossi C, Graziano C, Castorina P, Ambrosetti U, et al. 2015. Usher syndrome: An effective sequencing approach to establish a genetic and clinical diagnosis. Hear Res 320: 18-23.

Li Z, Anvari B, Takashima M, Brecht P, Torres JH, Brownell WE. 2002. Membrane tether formation from outer hair cells with optical tweezers. Biophys J 82: 1386-1395.

Lu Y, Zhou X, Jin Z, Cheng J, Shen W, Ji F, Liu L, Zhang X, Zhang M, Cao Y, et al. 2014. Resolving the genetic heterogeneity of prelingual hearing loss within one family: Performance comparison and application of two targeted next generation sequencing approaches. J Hum Genet 59: 599-607.

Maeda R, Kindt KS, Mo W, Morgan CP, Erickson T, Zhao H, Clemens-Grisham R, Barr-Gillespie PG, Nicolson T. 2014. Tip-link protein protocadherin 15 interacts with transmembrane channel-like proteins TMC1 and TMC2. Proc Natl Acad Sci 111: 12907-12912.

Maeda R, Pacentine IV, Erickson T, Nicolson T. 2017. Functional analysis of the transmembrane and cytoplasmic domains of Pcdh15a in zebrafish hair cells. J Neurosci 2216.

Mammano F, Bortolozzi M, Ortolano S, Anselmi F. 2007. $\mathrm{Ca}^{2+}$ signaling in the inner ear. Physiology 22: 131-144.

Manji SSM, Miller KA, Williams LH, Andreasen L, Siboe M, Rose E, Bahlo M, Kuiper M, Dahl HHM. 2011. An ENUinduced mutation of $C d h 23$ causes congenital hearing loss, but no vestibular dysfunction, in mice. Am J Pathol 179: 903-914.

Manley GA. 2017. Comparative auditory neuroscience: Understanding the evolution and function of ears. J Assoc Res Otolaryngol 18: 1-24.

Manley GA, Narins PM, Fay RR. 2012. Experiments in comparative hearing: Georg von Békésy and beyond. Hear Res 293: 44-50.

Markin VS, Hudspeth AJ. 1995. Gating-spring models of mechanoelectrical transduction by hair cells of the internal ear. Annu Rev Biophys Biomol Struct 24: 59-83.

Mathur P, Yang J. 2015. Usher syndrome: Hearing loss, retinal degeneration and associated abnormalities. Biochim Biophys Acta-Mol Basis Dis 1852: 406-420. 
McGee J, Goodyear RJ, McMillan DR, Stauffer EA, Holt JR, Locke KG, Birch DG, Legan PK, White PC, Walsh EJ, et al. 2006. The very large G-protein-coupled receptor VLGR1: A component of the ankle link complex required for the normal development of auditory hair bundles. J Neurosci 26: 6543-6553.

Michalski N, Michel V, Bahloul A, Lefèvre G, Barral J, Yagi H, Chardenoux S, Weil D, Martin P, Hardelin JP, et al. 2007. Molecular characterization of the ankle-link complex in cochlear hair cells and its role in the hair bundle functioning. J Neurosci 27: 6478-6488.

Michel V, Goodyear RJ, Weil D, Marcotti W, Perfettini I, Wolfrum U, Kros CJ, Richardson GP, Petit C. 2005. Cadherin 23 is a component of the transient lateral links in the developing hair bundles of cochlear sensory cells. Dev Biol 280: 281-294.

Miyagawa M, Nishio S, Usami S. 2012. Prevalence and clinical features of hearing loss patients with $\mathrm{CDH} 23$ mutations: A large cohort study. PLoS ONE 7: e40366.

Miyagawa M, Naito T, Nishio S, Kamatani N, Usami S. 2013. Targeted exon sequencing successfully discovers rare causative genes and clarifies the molecular epidemiology of Japanese deafness patients. PLoS ONE 8: e71381.

Moteki H, Azaiez H, Sloan-Heggen CM, Booth K, Nishio SY, Wakui K, Yamaguchi T, Kolbe DL, Iwasa YI, Shearer AE, et al. 2016. Detection and confirmation of deafnesscausing copy number variations in the STRC gene by massively parallel sequencing and comparative genomic hybridization. Ann Otol Rhinol Laryngol 125: 918-923.

Nagar B, Overduin M, Ikura M, Rini JM. 1996. Structural basis of calcium-induced E-cadherin rigidification and dimerization. Nature 380: 360-364.

Nicoludis JM, Vogt BE, Green AG, Schärfe CP, Marks DS, Gaudet R. 2016. Antiparallel protocadherin homodimers use distinct affinity- and specificity-mediating regions in cadherin repeats 1-4. Elife 5: e18449.

Oroz J, Valbuena A, Vera AM, Mendieta J, Gómez-Puertas P Carrión-Vázquez M. 2011. Nanomechanics of the cadherin ectodomain: "Canalization" by $\mathrm{Ca}^{2+}$ binding results in a new mechanical element. J Biol Chem 286: 94059418.

Oshima A, Jaijo T, Aller E, Millan JM, Carney C, Usami S, Moller C, Kimberling WJ. 2008. Mutation profile of the $\mathrm{CDH} 23$ gene in 56 probands with Usher syndrome type I. Hum Mutat 29: E37-E46.

Ouyang XM, Yan D, Du LL, Hejtmancik JF, Jacobson SG Nance WE, Li AR, Angeli S, Kaiser M, Newton V, et al. 2005. Characterization of Usher syndrome type I gene mutations in an Usher syndrome patient population. Hum Genet 116: 292-299.

Pan L, Zhang M. 2012. Structures of Usher syndrome 1 proteins and their complexes. Physiology 27: 25-42.

Pan L, Yan J, Wu L, Zhang M. 2009. Assembling stable hair cell tip link complex via multidentate interactions between harmonin and cadherin 23. Proc Natl Acad Sci 106: $5575-5580$.

Pan B, Géléoc GS, Asai Y, Horwitz GC, Kurima K, Ishikawa K, Kawashima Y, Griffith AJ, Holt JR. 2013. TMC1 and TMC2 are components of the mechanotransduction channel in hair cells of the mammalian inner ear. Neuron 79: 504-515.
Peng AW, Effertz T, Ricci AJ. 2013. Adaptation of mammalian auditory hair cell mechanotransduction is independent of calcium entry. Neuron 80: 960-972.

Peng AW, Gnanasambandam R, Sachs F, Ricci AJ. 2016. Adaptation independent modulation of auditory hair cell mechanotransduction channel open probability implicates a role for the lipid bilayer. J Neurosci 36: 2945-2956.

Pennings RJE, Topsakal V, Astuto L, de Brouwer APM, Wagenaar M, Huygen PLM, Kimberling WJ, Deutman AF, Kremer H, Cremers CWRJ. 2004. Variable clinical features in patients with $\mathrm{CDH} 23$ mutations (USH1DDFNB12). Otol Neurotol 25: 699-706.

Pepermans E, Michel V, Goodyear R, Bonnet C, Abdi S, Dupont T, Gherbi S, Holder M, Makrelouf M, Hardelin $\mathrm{J}$-P, et al. 2014. The CD2 isoform of protocadherin-15 is an essential component of the tip-link complex in mature auditory hair cells. EMBO Mol Med 6: 984-992.

Pickles JO, Corey DP. 1992. Mechanoelectrical transduction by hair cells. Trends Neurosci 15: 254-259.

Pickles JO, Comis SD, Osborne MP. 1984. Cross-links between stereocilia in the guinea pig organ of Corti, and their possible relation to sensory transduction. Hear Res 15: 103-112.

Pokutta S, Herrenknecht K, Kemler R, Engel J. 1994. Conformational changes of the recombinant extracellular domain of E-cadherin upon calcium binding. Eur J Biochem 223: 1019-1026.

Powers RJ, Roy S, Atilgan E, Brownell WE, Sun SX, Gillespie PG, Spector AA. 2012. Stereocilia membrane deformation: Implications for the gating spring and mechanotransduction channel. Biophys J 102: 201-210.

Powers RJ, Kulason S, Atilgan E, Brownell WE, Sun SX, BarrGillespie PG, Spector AA. 2014. The local forces acting on the mechanotransduction channel in hair cell stereocilia Biophys J 106: 2519-2528.

Powers RE, Gaudet R, Sotomayor M. 2017. A partial calcium-free linker confers flexibility to inner-ear protocadherin-15. Structure 25: 482-495.

Radice GL. 2013. N-cadherin-mediated adhesion and signaling from development to disease: Lessons from mice. Prog Mol Biol Transl Sci 116: 263-289.

Redies C, Hertel N, Hübner CA. 2012. Cadherins and neuropsychiatric disorders. Brain Res 1470: 130-144.

Reichenbach T, Hudspeth AJ. 2014. The physics of hearing: Fluid mechanics and the active process of the inner ear. Rep Prog Phys 77: 76601.

Rico F, Gonzalez L, Casuso I, Puig-Vidal M, Scheuring S. 2013. High-speed force spectroscopy unfolds titin at the velocity of molecular dynamics simulations. Science 342: 741-743.

Ringwald M, Schuh R, Vestweber D, Eistetter H, Lottspeich F, Engel J, Dölz R, Jähnig F, Epplen J, Mayer S. 1987. The structure of cell adhesion molecule uvomorulin. Insights into the molecular mechanism of $\mathrm{Ca}^{2+}$-dependent cell adhesion. EMBO J 6: 3647-3653.

Roux A-F, Faugère V, Le Guédard S, Pallares-Ruiz N, Vielle A, Chambert S, Marlin S, Hamel C, Gilbert B, Malcolm S, et al. 2006. Survey of the frequency of USH1 gene mutations in a cohort of Usher patients shows the importance 
A. Jaiganesh et al.

of cadherin 23 and protocadherin 15 genes and establishes a detection rate of above $90 \%$. J Med Genet 43: 763-768.

Roux A-F, Faugère V, Vaché C, Baux D, Besnard T, Léonard S, Blanchet C, Hamel C, Mondain M, Gilbert-Dussardier B, et al. 2011. Four-year follow-up of diagnostic service in USH1 patients. Investig Opthalmol Vis Sci 52: 4063-4071.

Sahly I, Dufour E, Schietroma C, Michel V, Bahloul A, Perfettini I, Pepermans E, Estivalet A, Carette D, Aghaie A, et al. 2012. Localization of Usher 1 proteins to the photoreceptor calyceal processes, which are absent from mice. J Cell Biol 199: 381-399.

Salt AN, Inamura N, Thalmann R, Vora A. 1989. Calcium gradients in inner ear endolymph. Am J Otolaryngol 10: 371-375.

Schietroma C, Parain K, Estivalet A, Aghaie A, Boutet de Monvel J, Picaud S, Sahel JA, Perron M, El-Amraoui A, Petit C. 2017. Usher syndrome type 1-associated cadherins shape the photoreceptor outer segment. J Cell Biol 216: 1849-1864.

Schultz JM, Yang Y, Caride AJ, Filoteo AG, Penheiter AR, Lagziel A, Morell RJ, Mohiddin SA, Fananapazir L, Madeo AC, et al. 2005. Modification of human hearing loss by plasma-membrane calcium pump PMCA2. $N$ Engl $J$ Med 352: 1557-1564.

Schultz JM, Bhatti R, Madeo AC, Turriff A, Muskett JA, Zalewski CK, King KA, Ahmed ZM, Riazuddin S, Ahmad $\mathrm{N}$, et al. 2011. Allelic hierarchy of $C D H 23$ mutations causing non-syndromic deafness DFNB12 or Usher syndrome USH1D in compound heterozygotes. J Med Genet 48: 767-775.

Schwander M, Xiong W, Tokita J, Lelli A, Elledge HM, Kazmierczak P, Sczaniecka A, Kolatkar A, Wiltshire T, Kuhn $P$, et al. 2009. A mouse model for nonsyndromic deafness (DFNB12) links hearing loss to defects in tip links of mechanosensory hair cells. Proc Natl Acad Sci 106: 5252-5257.

Schwander M, Kachar B, Müller U. 2010. Review series: The cell biology of hearing. J Cell Biol 190: 9-20.

Seiler C, Finger-Baier KC, Rinner O, Makhankov YV, Schwarz H, Neuhauss SCF, Nicolson T. 2005. Duplicated genes with split functions: Independent roles of protocadherin 15 orthologues in zebrafish hearing and vision. Development 132: 615-623.

Shahin H, Walsh T, Rayyan AA, Lee MK, Higgins J, Dickel D, Lewis K, Thompson J, Baker C, Nord AS, et al. 2010. Five novel loci for inherited hearing loss mapped by SNPbased homozygosity profiles in Palestinian families. Eur $J$ Hum Genet 18: 407-413.

Shen YY, Liang L, Li GS, Murphy RW, Zhang YP. 2012. Parallel evolution of auditory genes for echolocation in bats and toothed whales. PLoS Genet 8: e1002788.

Shepherd GM, Corey DP. 1994. The extent of adaptation in bullfrog saccular hair cells. J Neurosci 14: 6217-6229.

Shotwell SL, Jacobs R, Hudspeth AJ. 1981. Directional sensitivity of individual vertebrate hair cells to controlled deflection of their hair bundles. Ann NY Acad Sci 374: $1-10$.

Siemens J, Lillo C, Dumont RA, Reynolds A, Williams DS, Gillespie PG, Müller U. 2004. Cadherin 23 is a component of the tip link in hair-cell stereocilia. Nature 428: 950955 .
Sloan-Heggen CM, Babanejad M, Beheshtian M, Simpson AC, Booth KT, Ardalani F, Frees KL, Mohseni M, Mozafari R, Mehrjoo Z, et al. 2015. Characterising the spectrum of autosomal recessive hereditary hearing loss in Iran. J Med Genet 52: 823-829.

Sloan-Heggen CM, Bierer AO, Shearer AE, Kolbe DL, Nishimura CJ, Frees KL, Ephraim SS, Shibata SB, Booth KT, Campbell CA, et al. 2016. Comprehensive genetic testing in the clinical evaluation of 1119 patients with hearing loss. Hum Genet 135: 441-450.

Söllner C, Rauch GJ, Siemens J, Geisler R, Schuster SC, Müller U, Nicolson T, the Tübingen 2000 Screen Consortium. 2004. Mutations in cadherin 23 affect tip links in zebrafish sensory hair cells. Nature 428: 955-959.

Sotomayor M, Schulten K. 2008. The allosteric role of the $\mathrm{Ca}^{2+}$ switch in adhesion and elasticity of C-cadherin. Biophys J 94: 4621-4633.

Sotomayor M, Weihofen WA, Gaudet R, Corey DP. 2010. Structural determinants of cadherin-23 function in hearing and deafness. Neuron 66: 85-100.

Sotomayor M, Weihofen WA, Gaudet R, Corey DP. 2012. Structure of a force-conveying cadherin bond essential for inner-ear mechanotransduction. Nature 492: 128-132.

Sotomayor M, Gaudet R, Corey DP. 2014. Sorting out a promiscuous superfamily: Towards cadherin connectomics. Trends Cell Biol 24: 524-536.

Sukharev S, Corey DP. 2004. Mechanosensitive channels: Multiplicity of families and gating paradigms. Sci STKE 2004: re4.

Suzuki ST. 1996. Protocadherins and diversity of the cadherin superfamily. J Cell Sci 109: 2609-2611.

Syeda R, Florendo MN, Cox CD, Kefauver JM, Santos JS, Martinac B, Patapoutian A. 2016. Piezol channels are inherently mechanosensitive. Cell Rep 17: 1739-1746.

Takahashi S, Mui VJ, Rosenberg SK, Homma K, Cheatham MA, Zheng J. 2016. Cadherin 23-C regulates microtubule networks by modifying CAMSAP3's function. Sci Rep $\mathbf{6}$ : 28706.

Takeichi M. 1977. Functional correlation between cell adhesive properties and some cell surface proteins. J Cell Biol 75: $464-474$.

Takeichi M. 1990. Cadherins: A molecular family important in selective cell-cell adhesion. Annu Rev Biochem 59: 237-252.

Tsukasaki Y, Miyazaki N, Matsumoto A, Nagae S, Yonemura S, Tanoue T, Iwasaki K, Takeichi M. 2014. Giant cadherins Fat and Dachsous self-bend to organize properly spaced intercellular junctions. Proc Natl Acad Sci 111: 16011-16016.

Usami S-I, Wagatsuma M, Fukuoka H, Suzuki H, Tsukada K, Nishio S, Takumi Y, Abe S. 2008. The responsible genes in Japanese deafness patients and clinical application using Invader assay. Acta Otolaryngol 128: 446-454.

van Roy F, Berx G. 2008. The cell-cell adhesion molecule E-cadherin. Cell Mol Life Sci 65: 3756-3788.

Vélez-Ortega AC, Freeman MJ, Indzhykulian AA, Grossheim JM, Frolenkov GI. 2017. Mechanotransduction current is essential for stability of the transducing stereocilia in mammalian auditory hair cells. Elife 6: e24661.

Verpy E, Leibovici M, Michalski N, Goodyear RJ, Houdon C, Weil D, Richardson GP, Petit C. 2011. Stereocilin con- 
nects outer hair cell stereocilia to one another and to the tectorial membrane. J Comp Neurol 519: 194-210.

Von Békésy G. 1956. Current status of theories of hearing. Science 123: 779-783.

Wagatsuma M, Kitoh R, Suzuki H, Fukuoka H, Takumi Y, Usami S. 2007. Distribution and frequencies of $\mathrm{CDH} 23$ mutations in Japanese patients with non-syndromic hearing loss. Clin Genet 72: 339-344.

Webb SW, Grillet N, Andrade LR, Xiong W, Swarthout L, Della Santina CC, Kachar B, Müller U. 2011. Regulation of PCDH15 function in mechanosensory hair cells by alternative splicing of the cytoplasmic domain. Development 138: 1607-1617.

Woo HM, Park HJ, Park MH, Kim BY, Shin JW, Yoo WG, Koo SK. 2014. Identification of $\mathrm{CDH} 23$ mutations in Korean families with hearing loss by whole-exome sequencing. BMC Med Genet 15: 46.

Wu Z, Muller U. 2016. Molecular identity of the mechanotransduction channel in hair cells: Not quiet there yet. J Neurosci 36: 10927-10934.

Wu L, Pan L, Zhang C, Zhang M. 2012. Large protein assemblies formed by multivalent interactions between cadherin 23 and harmonin suggest a stable anchorage
Sensational Cadherins for Hearing and Balance

structure at the tip link of stereocilia. J Biol Chem 287: 33460-33471.

Wu Z, Grillet N, Zhao B, Cunningham C, Harkins-Perry S, Coste B, Ranade S, Zebarjadi N, Beurg M, Fettiplace R, et al. 2016. Mechanosensory hair cells express two molecularly distinct mechanotransduction channels. Nat Neurosci 20: 24-33.

Xiong W, Grillet N, Elledge HM, Wagner TFJ, Zhao B, Johnson KR, Kazmierczak P, Müller U. 2012. TMHS is an integral component of the mechanotransduction machinery of cochlear hair cells. Cell 151: 1283-1295.

Xu Z, Peng AW, Oshima K, Heller S. 2008. MAGI-1, a candidate stereociliary scaffolding protein, associates with the tip-link component cadherin 23. J Neurosci 28: 11269-11276.

Zhao Y, Yamoah EN, Gillespie PG. 1996. Regeneration of broken tip links and restoration of mechanical transduction in hair cells. Proc Natl Acad Sci 93: 15469-15474.

Zhao B, Wu Z, Grillet N, Yan L, Xiong W, Harkins-Perry S, Müller U. 2014. TMIE is an essential component of the mechanotransduction machinery of cochlear hair cells. Neuron 84: 954-967. 


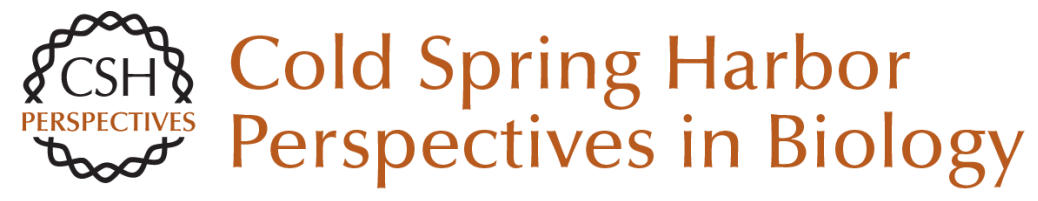

\section{Beyond Cell-Cell Adhesion: Sensational Cadherins for Hearing and Balance}

Avinash Jaiganesh, Yoshie Narui, Raul Araya-Secchi and Marcos Sotomayor

Cold Spring Harb Perspect Biol 2018; doi: 10.1101/cshperspect.a029280 originally published online August 28, 2017

\section{Subject Collection Cell-Cell Junctions}

Vascular Endothelial (VE)-Cadherin, Endothelial

Adherens Junctions, and Vascular Disease Maria Grazia Lampugnani, Elisabetta Dejana and Costanza Giampietro

Adherens Junctions and Desmosomes Coordinate Mechanics and Signaling to Orchestrate Tissue Morphogenesis and Function: An Evolutionary Perspective Matthias Rübsam, Joshua A. Broussard, Sara A. Wickström, et al.

Cell-Cell Contact and Receptor Tyrosine Kinase Signaling Christine Chiasson-MacKenzie and Andrea I. McClatchey

Hold Me, but Not Too Tight---Endothelial Cell-Cell Junctions in Angiogenesis

Anna Szymborska and Holger Gerhardt

Connexins and Disease Mario Delmar, Dale W. Laird, Christian C. Naus, et al.

Cell Junctions in Hippo Signaling Ruchan Karaman and Georg Halder
Signaling by Small GTPases at Cell-Cell Junctions: Protein Interactions Building Control and Networks Vania Braga

Making Connections: Guidance Cues and Receptors at Nonneural Cell-Cell Junctions lan V. Beamish, Lindsay Hinck and Timothy E. Kennedy

The Cadherin Superfamily in Neural Circuit Assembly James $D$. Jontes

Mechanosensing and Mechanotransduction at Cell-Cell Junctions Alpha S. Yap, Kinga Duszyc and Virgile Viasnoff

Beyond Cell-Cell Adhesion: Sensational

Cadherins for Hearing and Balance Avinash Jaiganesh, Yoshie Narui, Raul Araya-Secchi, et al.

Cell-Cell Junctions Organize Structural and Signaling Networks Miguel A. Garcia, W. James Nelson and Natalie Chavez

For additional articles in this collection, see http://cshperspectives.cshlp.org/cgi/collection/

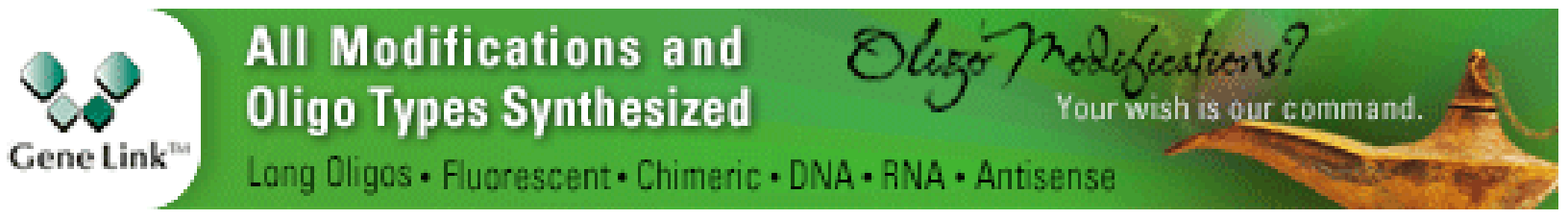


Loss of E-Cadherin-Dependent Cell-Cell Adhesion and the Development and Progression of Cancer Heather C. Bruner and Patrick W.B. Derksen

Desmosomes and Intermediate Filaments: Their Consequences for Tissue Mechanics

Mechthild Hatzfeld, René Keil and Thomas M. Magin
Cell Biology of Tight Junction Barrier Regulation and Mucosal Disease

Aaron Buckley and Jerrold R. Turner

Integration of Cadherin Adhesion and

Cytoskeleton at Adherens Junctions

René Marc Mège and Noboru Ishiyama

For additional articles in this collection, see http://cshperspectives.cshlp.org/cgi/collection/

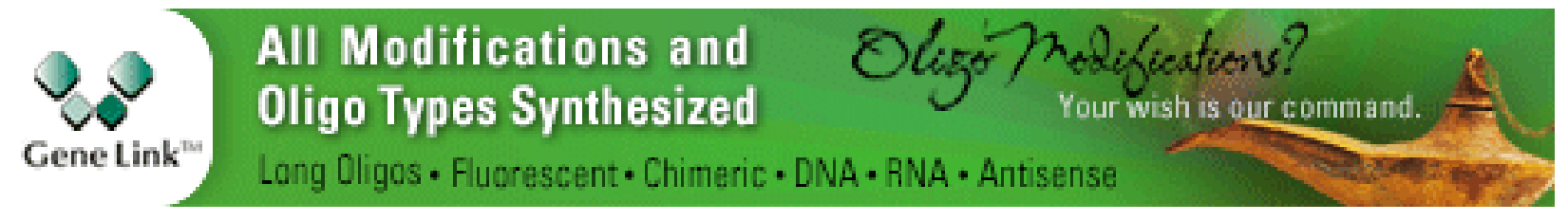

Copyright @ 2018 Cold Spring Harbor Laboratory Press; all rights reserved 